Provided for non-commercial research and education use. Not for reproduction, distribution or commercial use.

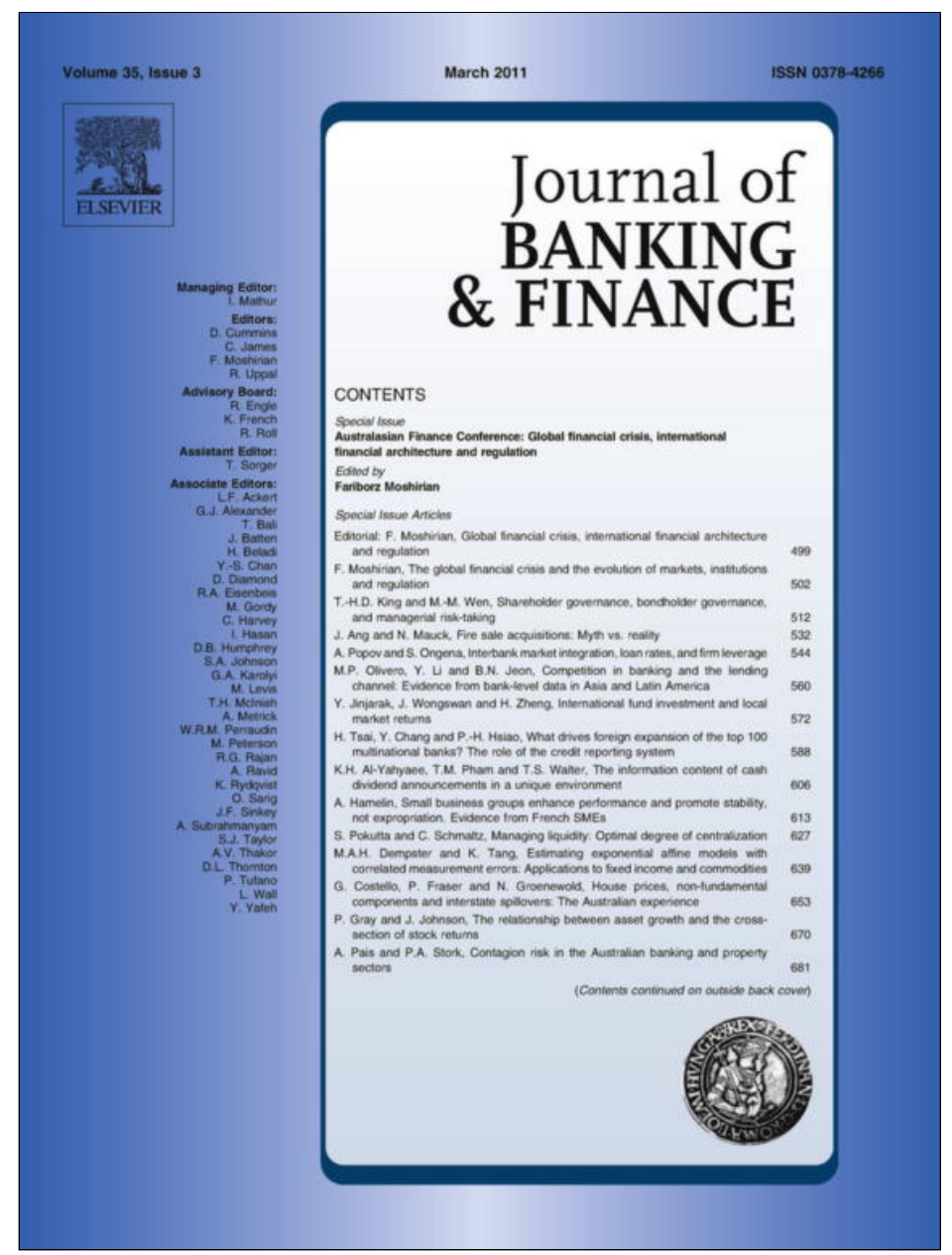

This article appeared in a journal published by Elsevier. The attached copy is furnished to the author for internal non-commercial research and education use, including for instruction at the authors institution and sharing with colleagues.

Other uses, including reproduction and distribution, or selling or licensing copies, or posting to personal, institutional or third party websites are prohibited.

In most cases authors are permitted to post their version of the article (e.g. in Word or Tex form) to their personal website or institutional repository. Authors requiring further information regarding Elsevier's archiving and manuscript policies are encouraged to visit:

http://www.elsevier.com/copyright 


\title{
International fund investment and local market returns
}

\author{
Yothin Jinjarak $^{\mathrm{a}, *}$, Jon Wongswan ${ }^{\mathrm{b}}$, Huanhuan Zheng ${ }^{\mathrm{a}}$ \\ ${ }^{a}$ Division of Economics, Nanyang Technological University, 14 Nanyang Avenue 637332, Singapore \\ ${ }^{\mathrm{b}}$ Phatra Securities Public Company Limited, 252/6 Ratchadapisek Road, Bangkok 10310, Thailand
}

\section{A R T I C L E I N F O}

\section{Article history:}

Received 5 November 2009

Accepted 2 April 2010

Available online 13 April 2010

\section{JEL classification:}

E44

F37

G15

Keywords:

Asset returns

Bonds and equities

Capital flows

Institutional investors

Global integration

\begin{abstract}
A B S T R A C T
International fund investment in bonds and equities is characterized by a positive association between current net inflows and contemporaneous and past market returns: positive-feedback trading, while being possibly profitable for international fund investors, could be destabilizing for the underlying markets. Allowing for interactions between equity investment and bond investment, our panel vector autoregression shows that past equity returns contain useful information in forecasting equity and bond flows and that bond flows impact future equity returns positively.
\end{abstract}

(c) 2010 Elsevier B.V. All rights reserved.

\section{Introduction}

The financial globalization of the past three decades has led to large two-way capital flows that have brought with them the benefits of global risk-sharing and real productivity improvement but have periodically ended in financial calamities and crises. Consequently, a frequent concern of academics and policy makers focuses on the dynamics of portfolio flows, which can amplify the boom-bust cycles of local asset prices and spread financial trouble across countries and regional markets. ${ }^{1}$

By and large, previous studies investigating the relationship between cross-border flows and returns have devoted substantial effort toward equity investment and tend to find a positive association between contemporaneous net inflows and local

\footnotetext{
* Corresponding author. Tel.: +65 6790 6798; fax: +65 67946303.

E-mail addresses: YJinjarak@ntu.edu.sg (Y. Jinjarak), Jon@phatrasecurities.com (J. Wongswan), H070010@ntu.edu.sg (H. Zheng).

1 See for example Claessens et al. (1995), Levchenko and Mauro (2007), Broner et al. (2006), Ferreira and Laux (2009), and Smith and Valderrama (2009). Using monthly US capital flows to Latin American and Asian countries, Chuhan et al. (1998) find that global factors (the drop in US interest rates and the slowdown in US industrial production) and country-specific developments are important in explaining capital inflows. De Santis and Lührmann (2009) find that population aging institutions, money and deviations from the Uncovered Interest Parity (UIP) influence developments in net capital flows.
}

market returns. ${ }^{2}$ Their primary focus is to understand a strategic portfolio investment by institutional investors in the equity market across countries. There are now dozens of studies on institutional investment and market returns, led, for example, by the early works on the US markets of Lakonishok et al. (1992) and Warther (1995). The former has provided much of our understanding on two aspects of trading by institutional investors: herding, which refers to simultaneously buying (selling) the same stocks that other managers are buying (selling), and positive-feedback trading, which refers to buying past winners and selling past losers. Using monthly and weekly data, Warther (1995) examines aggregated mutual fund flows and returns (the cash flows into or out of all mutual funds and marketwide returns), and finds evidence of a positive relation between flows and subsequent returns as well as evidence of a negative relation between returns and subsequent flows. Later studies including Froot et al. (2001) and Kaminsky et al. (2004) have gone beyond national boundaries, extending the literature by studying institutional equity investment across a larger set of countries at various stages of financial development.

\footnotetext{
${ }^{2}$ A related strand of the literature studies the determinants of cross-border portfolio flows and holdings. For aggregate flow data, see Aviat and Coeurdacier (2007), Portes and Rey (2005), and Gelos and Wei (2005). For fund-level flow data, see also Griffin et al. (2004) for daily data or Froot and Ramadorai (2008b) for weekly data.
} 
In a seminal contribution based on the 1994-1998 data, Froot et al. (2001) show that inflows of equity capital have a positive forecasting power for future equity returns in emerging markets and that international investors follow positive trading strategies, which cause money to tend to move into markets that have recently performed well. The implication is that, except for the crisis-prone emerging markets of the 1990s, the transmission of shocks across national markets might not primarily result from the actions of international investors; the investors simply react, with lags, to public information. Nevertheless, theirs and existing findings from the previous decade need updating and call into question the possibility of regional correlations and countryspecific factors since then, which can influence the international fund investment and local market returns in the post market liberalization era. In addition, the majority of works so far have dealt only with equity markets, leaving unexplored the dynamics of international bond investment and its interaction with equity returns. $^{3}$

We fill the gap by providing new evidence on the relationship between international portfolio flows and returns for both equity and bond funds. To the best of our knowledge, this paper is the first to address international flows-returns comovements together with the interaction between equity and bond investment across countries. Our sample aggregates portfolio flows of international fund investment in 67 countries, with total asset holdings of about 10 trillion USD as of 2008 (the world's total bond and equity market capitalization is 116 trillion USD). The length of data spans from 1995 to 2008, which allows us to investigate characteristics of net inflows (i.e., persistence and covariance with local market returns) and to formally summarize the interactions between international fund investment and local market returns using vector autoregressive representation of individual countries and in a panel. ${ }^{4}$

Our novel contribution can also be directed to a broader finance-macro issue on the joint determinants of banking, bond and equity flows to emerging markets. Sarno and Taylor (1999) find relatively low permanent components in equity flows and bond flows, while commercial bank flows appear to contain quite large permanent components and FDI flows are almost entirely permanent. Recently, Baele et al. (in press) show that macroeconomic fundamentals contribute little to explaining stock and bond return correlations but that other factors, especially liquidity proxies, play a more important role. By examining the bond and equity investment of international funds, our analysis seeks to synchronize the literature and to better understand how the short- to medium-run dynamics of capital flows and local market returns are influenced by international investors.

The study is organized as follows. Section 2 describes the data. Section 3 formally tests the comovements between international fund flows and local market returns. Section 4 examines the interactions between equity and bond investment. Section 5 concludes.

\footnotetext{
${ }^{3}$ The exception is Warther (1995), who studies both equity and bond funds in US. Other considerations include the trend that bond funds have increased in size and number in recent years, which accounts for an increasing proportion of international portfolio holdings, especially in the case of Latin American bond funds. Another is the notion of the pecking order of capital flows and international investment (i.e., Razin et al., 198) and Daude and Fratzscher, 2008).

${ }^{4}$ Our sample and evidence can also be viewed as an extension to the study by Bekaert et al. (2002), which examines the relationship between equity flows and returns during the pre- and post-1990 periods (liberalization breaks) in twenty emerging markets. Their estimates show that, as a result of structural breaks, shocks in equity flows initially increase returns (price pressure), but the effect is diminished over time.
}

\section{Data and characteristics of international fund investment}

We collect monthly data on market returns, international fund flows and allocations from the EPFR Global. In terms of the representativeness of our cross-country data, this database tracks equity and bond funds that invest globally; which together hold about $\$ 10$ trillion in total assets as of 2008 (the world's total bond and equity market capitalization is 116 trillion USD). Based on the fund-level information, monthly net inflows are aggregated to the level of country and regional destinations. Our sample of equity-fund investment is from March 1995 to November 2008, covering international net inflows (US dollars) to 67 countries, of which 20 are developed countries and 47 are emerging markets. The sample of bond-fund investment is from January 2004 to January 2008, covering 29 emerging-market destinations. A sample correlation between market capitalization and the holdings of international equity funds (bond funds) is $0.9(0.2)$. Table 1 provides the list of countries and regions available in the sample.

While this study examines international funds in the EPFR Global database, we note that there are two alternative databases on international fund investment. Thomson Financial Securities (TFS) provides quarterly information on the global equity holdings of mutual funds as well as targeted equities. The main advantage of the TFS is provided by the details of assets down to the equity level. Hau and Rey (2008) study international fund investment using TFS during 1997-2002, and Chan et al. (2005) for the years 1999 and 2000. The second database is the State Street Bank and Trust (SSB), which has the benefit of high-frequency daily information and is studied by Froot et al. (2001). In comparison with TFS and SSB, the information in EPFR therefore has a lower frequency than the daily SSB data (but higher than the TFS) and does not cover asset holdings at the equity level of the quarterly TFS data. It is likely that low- and high-frequency data tend to provide different dynamics of flows and returns. ${ }^{5}$ It is also possible that the evidence would depend on whether the data are proprietary or publicly available. However, the key advantages of EPFR database are the longer period, the coverage of both international bond and equity funds, and the most recent information, which makes our sample the most suitable for studying the role of market integration and medium-run dynamics of the flows-returns relationship. ${ }^{6}$

\subsection{Descriptive statistics}

Following Froot et al. (2001), we scale the net inflows $\left(F_{i, t}\right.$ ) by total asset holdings $\left(M_{i, t}\right)$ :

$f_{i, t}=\frac{F_{i, t}}{M_{i, t}}$

where $i$ denotes region (or country) and $t$ monthly time period.

Table 1 reports descriptive statistics of our sample at the regional and country levels for the equity funds in Panel A and bond funds in Panel B. Regarding the international fund investment in equities, from March 1995 to June 2008, the monthly global average holding is 293 billion USD. As we can see in Table 1, the asset holdings of international equity funds in our sample are heavily concentrated in emerging markets; at the country level, the largest average holdings are in Japan, followed by the UK, the US and the BRIC countries. Over the sample period, emerging markets register positive net inflows (average, total, or scaled by market capitalization), whereas the net inflows of the overall developed markets are

\footnotetext{
5 See discussions in Froot et al. (2001) and Rakowski and Wang (2009).

${ }^{6}$ Furthermore, in comparison to the official data such as the US Treasury's TIC, our EPFR data overcome the problem of the misreporting of transactions of foreign-based firms or intermediaries trading on behalf of US investors. See Froot et al. (2001) for detailed discussions on the weakness of official flows vs. fund-based data.
} 
Table 1

Descriptive statistics of holdings and net inflows. The sample period is March 1995 to November 2008 for international equity funds (Panel A, 67 countries), and January 2004 to November 2008 for international bond funds (Panel B, 29 countries). The sample is monthly, in million US dollars. Total net inflows (purchases minus sales) to market capitalization is an average over the sample period of annual net inflows divided by market capitalization. The data are derived from EPFR Global.

\begin{tabular}{|c|c|c|c|c|c|c|c|}
\hline Region/country & $\begin{array}{l}\text { Average } \\
\text { holdings }\end{array}$ & $\begin{array}{l}\text { Standard } \\
\text { deviation }\end{array}$ & $\begin{array}{l}\text { Average } \\
\text { deviation }\end{array}$ & $\begin{array}{l}\text { Standard } \\
\text { deviation }\end{array}$ & $\begin{array}{l}\text { Total net } \\
\text { inflows }\end{array}$ & $\begin{array}{l}\text { Net inflows to market } \\
\text { capitalization }\end{array}$ & $\begin{array}{l}\text { Standard } \\
\text { deviation }\end{array}$ \\
\hline \multicolumn{7}{|l|}{ Panel A: Equity funds } & \\
\hline All developed & 176,207 & 124,643 & -767 & 2,924 & $-52,140$ & -.002 & .019 \\
\hline North America & 32,737 & 22,357 & 135 & 876 & 9,207 & .006 & .034 \\
\hline Europe & 143,470 & 103,424 & -902 & 2,408 & $-61,347$ & -.004 & .019 \\
\hline Pacific & 55,171 & 46,104 & -7 & 1,298 & -743 & .002 & .025 \\
\hline All emerging & 234,389 & 162,799 & 58 & 2,670 & 9,181 & .000 & .011 \\
\hline Emerging Asia & 86,569 & 67,897 & 143 & 1,691 & 22,674 & .003 & .016 \\
\hline $\begin{array}{l}\text { Emerging Europe and } \\
\text { Middle East }\end{array}$ & 27,764 & 25,890 & 32 & 754 & 4,786 & .004 & .021 \\
\hline Latin America & 27,074 & 17,156 & -115 & 614 & $-18,272$ & -.004 & .020 \\
\hline \multicolumn{8}{|l|}{ Individual country } \\
\hline Argentina & 1,501 & 1,145 & -15 & 128 & $-2,440$ & -.009 & .087 \\
\hline Australia & 8,712 & 7,120 & -6 & 275 & -621 & -.005 & .028 \\
\hline Austria & 1,963 & 1,736 & 7 & 96 & 478 & .015 & .060 \\
\hline Bangladesh & 18 & 23 & -1 & 4 & -93 & .017 & .334 \\
\hline Belgium & 2,071 & 1,784 & -16 & 137 & $-1,093$ & -.023 & .132 \\
\hline Botswana & 11 & 9 & 0 & 7 & -55 & .005 & .465 \\
\hline Brazil & 13,885 & 13,550 & -38 & 422 & $-6,058$ & -.001 & .026 \\
\hline Bulgaria & 71 & 38 & -1 & 17 & -39 & .138 & 1.202 \\
\hline Canada & 4,663 & 3,449 & 6 & 208 & 386 & -.001 & .047 \\
\hline Chile & 1,710 & 373 & -9 & 72 & $-1,427$ & -.004 & .040 \\
\hline China & 12,720 & 20,112 & 95 & 664 & 15,082 & .016 & .065 \\
\hline Colombia & 180 & 152 & 0 & 18 & -57 & -.002 & .129 \\
\hline Croatia & 192 & 85 & -5 & 29 & -548 & -.017 & .127 \\
\hline Czech Republic & 1,058 & 838 & -14 & 55 & $-2,126$ & -.004 & .046 \\
\hline Denmark & 1,200 & 618 & -9 & 88 & -630 & -.008 & .068 \\
\hline Ecuador & 16 & 8 & -1 & 4 & -16 & -.110 & .286 \\
\hline Egypt & 635 & 730 & -4 & 82 & -567 & .016 & .098 \\
\hline Estonia & 80 & 41 & -3 & 20 & -327 & -.021 & .135 \\
\hline Finland & 3,549 & 2,067 & -39 & 157 & $-2,638$ & -.011 & .051 \\
\hline France & 19,348 & 14,771 & -46 & 470 & $-3,140$ & -.001 & .044 \\
\hline Germany & 19,286 & 16,561 & -122 & 569 & $-8,269$ & .001 & .030 \\
\hline Ghana & 23 & 17 & -1 & 8 & -86 & -.016 & .235 \\
\hline Greece & 892 & 871 & -8 & 62 & $-1,224$ & -.007 & .085 \\
\hline Hongkong & 14,555 & 6,983 & -25 & 430 & $-3,971$ & -.001 & .028 \\
\hline Hungary & 2,020 & 1,496 & -27 & 88 & $-4,064$ & -.008 & .038 \\
\hline India & 11,512 & 10,717 & 22 & 346 & 3,531 & .004 & .030 \\
\hline Indonesia & 2,659 & 1,731 & -11 & 101 & $-1,793$ & -.001 & .040 \\
\hline Ireland & 1,595 & 1,219 & -31 & 98 & $-2,092$ & -.026 & .101 \\
\hline Israel & 1,516 & 1,153 & 8 & 77 & 1,249 & .010 & .056 \\
\hline Italy & 7,368 & 5,960 & -45 & 280 & $-3,042$ & -.009 & .054 \\
\hline Japan & 55,433 & 37,390 & 4 & 1,375 & 317 & .006 & .026 \\
\hline Jordan & 11 & 10 & 1 & 5 & 32 & .693 & 3.475 \\
\hline Kenya & 1 & 1 & 0 & 1 & 6 & -.038 & .877 \\
\hline Korea & 18,107 & 13,599 & -54 & 463 & $-8,599$ & .005 & .035 \\
\hline Lebanon & 18 & 20 & -2 & 10 & -50 & -.012 & .723 \\
\hline Lithuania & 42 & 20 & 0 & 8 & -12 & -.005 & .168 \\
\hline Malaysia & 4,064 & 2,678 & -2 & 226 & -324 & .003 & .077 \\
\hline Mauritius & 17 & 5 & 0 & 2 & -10 & -.012 & .076 \\
\hline Mexico & 9,208 & 3,743 & -48 & 247 & $-7,630$ & -.003 & .026 \\
\hline Morocco & 72 & 64 & -2 & 11 & -237 & -.004 & .172 \\
\hline Netherlands & 10,444 & 6,439 & -136 & 445 & $-9,274$ & -.005 & .039 \\
\hline New Zealand & 264 & 63 & -4 & 19 & -426 & -.014 & .069 \\
\hline Norway & 1,877 & 1,586 & 2 & 148 & 143 & .001 & .107 \\
\hline Pakistan & 216 & 238 & 4 & 23 & 646 & .000 & .161 \\
\hline Peru & 428 & 267 & -2 & 33 & -263 & -.009 & .067 \\
\hline Philippines & 1,472 & 893 & 0 & 54 & -12 & .001 & .036 \\
\hline Poland & 2,213 & 1,613 & -6 & 76 & -925 & .004 & .038 \\
\hline Portugal & 403 & 305 & -6 & 43 & -855 & -.003 & .143 \\
\hline Romania & 90 & 72 & 0 & 15 & -20 & .018 & .276 \\
\hline Russia & 10,161 & 12,932 & 88 & 431 & 13,153 & .008 & .054 \\
\hline Singapore & 5,142 & 4,138 & 5 & 157 & 836 & .000 & .031 \\
\hline Slovakia & 12 & 13 & -1 & 6 & -37 & -.034 & .460 \\
\hline Slovenia & 32 & 17 & -1 & 7 & -74 & -.004 & .195 \\
\hline South Africa & 5,782 & 4,377 & 4 & 188 & 556 & .008 & .035 \\
\hline Spain & 6,810 & 4,748 & -68 & 213 & $-4,624$ & -.009 & .041 \\
\hline Sri Lanka & 123 & 82 & 0 & 9 & 8 & .000 & .107 \\
\hline Sweden & 3,934 & 2,237 & -36 & 202 & $-2,454$ & .001 & .090 \\
\hline Switzerland & 16,507 & 11,770 & -43 & 421 & $-2,942$ & .001 & .044 \\
\hline Taiwan & 11,945 & 9,289 & 102 & 381 & 16,146 & .012 & .042 \\
\hline
\end{tabular}


Table 1 (continued)

\begin{tabular}{|c|c|c|c|c|c|c|c|}
\hline Region/country & $\begin{array}{l}\text { Average } \\
\text { holdings }\end{array}$ & $\begin{array}{l}\text { Standard } \\
\text { deviation }\end{array}$ & $\begin{array}{l}\text { Average } \\
\text { deviation }\end{array}$ & $\begin{array}{l}\text { Standard } \\
\text { deviation }\end{array}$ & $\begin{array}{l}\text { Total net } \\
\text { inflows }\end{array}$ & $\begin{array}{l}\text { Net inflows to market } \\
\text { capitalization }\end{array}$ & $\begin{array}{l}\text { Standard } \\
\text { deviation }\end{array}$ \\
\hline Thailand & 4,036 & 2,520 & 8 & 136 & 1,206 & .002 & .035 \\
\hline Tunisia & 5 & 8 & -1 & 4 & -18 & -.051 & .244 \\
\hline Turkey & 3,026 & 2,544 & 2 & 125 & 266 & .004 & .037 \\
\hline UK & 47,140 & 32,705 & -324 & 884 & $-22,010$ & -.004 & .018 \\
\hline Ukraine & 132 & 37 & 1 & 17 & 43 & .014 & .134 \\
\hline USA & 28,074 & 19,466 & 130 & 779 & 8,819 & .008 & .035 \\
\hline Venezuela & 160 & 154 & -3 & 18 & -395 & -.029 & .208 \\
\hline Zimbabwe & 27 & 33 & -1 & 12 & -114 & .021 & 1.018 \\
\hline \multicolumn{8}{|l|}{ Panel B: Bond funds } \\
\hline All emerging & 17,730 & 6,889 & 141 & 603 & 7,637 & .011 & .034 \\
\hline Emerging Asia & 2,252 & 1,165 & 41 & 113 & 2,199 & .026 & .071 \\
\hline Emerging Europe and Middle East & 5,654 & 2,109 & 27 & 275 & 1,451 & .008 & .049 \\
\hline Latin America & 9,823 & 3,878 & 74 & 442 & 3,987 & .010 & .037 \\
\hline \multicolumn{8}{|l|}{ Individual country } \\
\hline Argentina & 1,545 & 1,006 & 24 & 212 & 1,305 & .048 & .133 \\
\hline Brazil & 3,148 & 1,086 & 13 & 149 & 680 & .005 & .052 \\
\hline Bulgaria & 56 & 39 & -3 & 8 & -173 & -.058 & .133 \\
\hline Chile & 70 & 30 & 0 & 11 & -19 & .016 & .187 \\
\hline China & 158 & 133 & 6 & 36 & 317 & .127 & .600 \\
\hline Colombia & 486 & 261 & 6 & 29 & 329 & .011 & .062 \\
\hline Dominican Republic & 88 & 35 & 1 & 8 & 37 & .004 & .087 \\
\hline Ecuador & 154 & 52 & -1 & 21 & -53 & .028 & .214 \\
\hline Egypt & 72 & 59 & 4 & 14 & 203 & 1.534 & 10.096 \\
\hline El Salvador & 77 & 38 & 1 & 7 & 71 & .014 & .103 \\
\hline Hungary & 323 & 126 & -4 & 56 & -212 & .005 & .156 \\
\hline Ivory Coast & 29 & 15 & 0 & 1 & -7 & -.016 & .068 \\
\hline Lebanon & 9 & 4 & 0 & 2 & -9 & -.015 & .138 \\
\hline Malaysia & 565 & 529 & 19 & 74 & 1,028 & .040 & .121 \\
\hline Mexico & 1,721 & 580 & 20 & 117 & 1,054 & .013 & .064 \\
\hline Morocco & 11 & 7 & -1 & 1 & -27 & -.077 & .201 \\
\hline Nigeria & 140 & 100 & 4 & 41 & 222 & .049 & .245 \\
\hline Panama & 226 & 66 & 1 & 16 & 65 & .009 & .065 \\
\hline Peru & 463 & 190 & 6 & 21 & 337 & .020 & .051 \\
\hline Philippines & 1,185 & 426 & 14 & 66 & 731 & .019 & .078 \\
\hline Poland & 809 & 345 & -4 & 98 & -226 & .010 & .116 \\
\hline Russia & 2,651 & 974 & 16 & 144 & 868 & .010 & .062 \\
\hline South Africa & 147 & 60 & -1 & 41 & -49 & .017 & .239 \\
\hline Thailand & 344 & 188 & 2 & 33 & 122 & .049 & .315 \\
\hline Tunisia & 46 & 14 & 0 & 3 & -21 & -.010 & .059 \\
\hline Turkey & 951 & 504 & 8 & 114 & 431 & .018 & .141 \\
\hline Ukraine & 412 & 202 & 8 & 30 & 450 & .036 & .115 \\
\hline Uruguay & 393 & 256 & 3 & 30 & 180 & .028 & .090 \\
\hline Venezuela & 1,452 & 663 & 0 & 219 & 2 & .006 & .111 \\
\hline
\end{tabular}

negative, driven mainly by the net outflows from Europe. Based on the standard deviations, the aggregate flows of international equity funds in our sample are highly volatile, fitting the characterization of hot money.

On the international fund investment in emerging-market bonds, the largest holdings are in Latin America (9.8 billion USD), followed by emerging markets in Europe and the Middle East (5.6 billion USD). While we only have the information for the recent four-year period from January 2004-2008, the sample is in line with the historical accounts of the Brady plan and the Russian crisis of the late 1990s in that the holdings of international bond funds in our sample are concentrated in Argentina, Brazil, Mexico, Philippines, Russia, and Venezuela. The net inflows and holdings of bonds in emerging-market Asia are also sizable (2.3 billion USD and 2.2 billion USD, respectively) during this period, underlined by cooperative efforts for the greater development of bond markets in the region. ${ }^{7}$

\subsection{Persistence of net inflows}

To understand first the persistence of net inflows, we compute the variance ratio statistics:

\footnotetext{
${ }^{7}$ See Eichengreen (2006)
}

$$
V R_{i}^{k}=\frac{\sum_{t=k}^{T}\left[\sum_{j}^{k-1}\left(f_{i, t-j}-\bar{f}_{i}\right)^{2}\right]}{k \sum_{j}^{k-1}\left(f_{i, t-j}-\bar{f}_{i}\right)^{2}} \frac{T-1}{(T-k-1)(1-k / T)} .
$$

The $V R_{i}^{k}$ statistic compares the variance of monthly net inflows with the variance of net inflows measured over $k=2,3,6$, and 12month intervals. Table 2 reports the $V R_{i}^{k}$ together with the heteroskedasticity-consistent $t$-test. The variance ratios, which are greater than one and statistically significant, suggest that the net inflows are persistent. While the results vary with the monthly intervals of calculation, the net inflows of international funds in our sample are largely persistent for equity investment (Panel A, except for the European markets), whereas they are not persistent for bond investment (Panel B). The reason might be that the bond sample is much shorter than the equity sample; however, at $k=2$ months, the net inflows of bonds are still much less persistent than is equity investment in emerging markets. Note that the variance ratios increase significantly with time horizon $k$, indicating that flows are more persistent at lower frequencies. Like Froot et al. (2001), we find no indication of leveling off in flow persistence. Equity flows are more persistent in emerging markets than they are in developed markets; flows to Europe are the least persistent in the developed markets, while flows to Asia are the least per- 
Table 2

Variance ratio statistics: This table reports the variance ratio statistics $V R_{i}(k)=\frac{\sum_{t=k}^{T}\left[\sum_{j}^{k-1}\left(f_{i, t-j}-\bar{f}_{i}\right)^{2}\right]}{k \sum_{j}^{k-1}\left(f_{i, t-j}-\bar{f}_{i}\right)^{2}} \frac{T-1}{(T-k-1)(1-k / T)}$, which compare the variance of monthly net inflows with the variance of net inflows measured over $k=2,3,6$, and 12-month intervals. The variance ratios use overlapping intervals and are corrected for bias in the variance estimators. Standard errors are asymptotic and heteroskedasticity-consistent. The sample period is March 1995 to June 2008 for equity funds (Panel A), and January 2004 to June 2008 for bond funds (Panel B).

\begin{tabular}{|c|c|c|c|c|c|c|c|c|}
\hline Region & $V R(2)$ & $t$-Statistics & $\operatorname{VR}(3)$ & $t$-Statistics & $\operatorname{VR}(6)$ & $t$-Statistics & $V R(12)$ & $t$-Statistics \\
\hline \multicolumn{9}{|l|}{ Panel A: Equity funds } \\
\hline All developed & 1.163 & 2.843 & 1.243 & 2.683 & 1.441 & 2.833 & 1.909 & 3.612 \\
\hline North America & 1.089 & .804 & 1.177 & 1.179 & 1.528 & 2.449 & 2.601 & 4.710 \\
\hline Europe & 1.165 & 1.504 & 1.206 & 1.292 & 1.318 & 1.295 & 1.443 & 1.272 \\
\hline Pacific & 1.497 & 4.012 & 1.793 & 4.417 & 2.165 & 4.034 & 2.486 & 3.585 \\
\hline All emerging & 1.239 & 2.763 & 1.365 & 2.708 & 1.625 & 2.714 & 1.718 & 2.069 \\
\hline Emerging Asia & 1.273 & 3.417 & 1.439 & 3.672 & 1.632 & 3.214 & 1.507 & 1.727 \\
\hline Emerging Europe and Middle East & 1.285 & 3.654 & 1.463 & 4.085 & 1.882 & 4.793 & 2.654 & 5.810 \\
\hline Latin America & 1.149 & 1.896 & 1.326 & 2.796 & 1.748 & 3.875 & 2.506 & 5.242 \\
\hline \multicolumn{9}{|l|}{ Panel B: Bond funds } \\
\hline All emerging & 1.096 & .694 & 1.069 & .343 & 1.184 & .567 & 1.783 & 1.576 \\
\hline Emerging Asia & 1.040 & .232 & .886 & -.469 & .629 & -.894 & 1.040 & .062 \\
\hline Emerging Europe and Middle East & 1.016 & .103 & .984 & -.071 & 1.227 & .647 & 1.813 & 1.580 \\
\hline Latin America & 1.061 & .450 & 1.134 & .701 & 1.248 & .757 & 1.489 & .942 \\
\hline
\end{tabular}

sistent in emerging markets for both equity and bond flows. Further, our results do not lend support to the notion that persistence is greater in larger markets; net inflows of equity investment to emerging-market Asian, European, and Latin American countries are generally more persistent than their aggregate or even inflows to developed markets.

\subsection{Covariance of net inflows and local market returns}

We now put together the net inflows of international fund investment and local market returns. Fig. 1 provides the heatmaps of monthly local market returns (top panel) and net inflows (bottom panel) for the equity investment (part a) and bond investment (part b) of international funds in our sample. We do not examine here whether correlation is related to market volatility, nor do we distinguish between correlations in the bear and bull markets (as done in Longin and Solnik, 2001). Nevertheless, we can see that the between-country correlations of both net inflows and local market returns are stronger for the group of countries within the same region. This is particularly the case for equity investment in developed European markets, followed by emerging-market Asia and Latin America, but less so for bond investment. The observed pattern of cross-country correlations for equity returns is consistent with Bekaert et al. (2009) that there are significant and increasing equity return correlations for the European equity markets, and that the regional effect is an important element in the international equity return comovements (see also Brooks and Del Negro, 2005).

Hence, as a benchmark, we will organize the estimation results focusing on the regional evidence along with supplemental discussion on the country-level estimates.

Fig. 2 plots the detrended cumulative net inflows and cumulative local market returns for equity-fund investment in emerging markets. The positive comovements are evident in the sample. The ADF test also shows that these two series are trend stationary. Following Froot et al. (2001), we first decompose the comovements between the two using a covariance ratio statistic (CVR):

$$
\begin{aligned}
C V R_{i}^{k}= & \sum_{j=1}^{k-1}\left(1-\frac{j}{k}\right) \beta\left(r_{i, t-j}, f_{i, t}\right)+\beta\left(r_{i, t}, f_{i, t}\right) \\
& +\sum_{j=1}^{k-1}\left(1-\frac{j}{k}\right) \beta\left(r_{i, t+j}, f_{i, t}\right),
\end{aligned}
$$

where $\beta\left(r_{i, j}, f_{i, t}\right)$ is the coefficient from regressing $r_{i, j}$ on $f_{i, t}$. We calculate the CVR statistics using $k=12$. This decomposition can be broken down into three parts. The first part decomposes the lag effects of returns on flows $\equiv \sum_{j=1}^{k-1}\left(1-\frac{j}{k}\right) \beta\left(r_{i, t-j}, f_{i, t}\right)$ into four parts, with the break points at lags of $2,3,6$ and 12 . The second part provides the contemporary effect, $\beta\left(r_{i, t}, f_{i, t}\right)$. The third part decomposes the lead effects $\equiv \sum_{j=1}^{k-1}\left(1-\frac{j}{k}\right) \beta\left(r_{i, t+j}, f_{i, t}\right)$ into four parts, with the break points at leads of 2, 3, 6 and 12 . The CVR statistic is obtained by making an equal-weighted index of flows within a given region.

The covariance ratio statistic provides a standardized crosscovariance between current flows and contemporaneous, past and future returns spanning 12 months. Fig. 3 summarizes the decomposition of the covariance ratio statistic for 12 -month returns against 12-month net inflows. ${ }^{8}$ The general pattern is that the contemporaneous effects (the second term) account for most of the 12-month covariance, followed by the covariance between current flows and past returns (the first term), and the covariance between current flows and future returns (the third term). Current and past returns are positively associated with contemporaneous net inflows of international investment for both equity and bond funds.

Across the markets, the decomposition of CVR statistics shows some variation. For international equity investment, comparing between the emerging and developed markets, the CVR pattern is about the same, as is the importance of the contemporaneous effect ( $44 \%$ and $46 \%$, respectively). For the bond investment, Latin America registered the largest CVR, driven mainly by the comovements between past returns and current net inflows. On the other hand, the CVR of the emerging markets in Europe is about half that of Latin America, with the contemporaneous effect accounting for more than $50 \%$ of the comovements between net inflows and local market returns.

The markets variation of the comovements between the net inflows and local returns as suggested by the CVR statistics fit into several competing hypotheses in the literature. As shown in Fig. 3, the comovements between past local market returns and current net inflows (lag effects) account for a larger proportion of the CVR than do the comovements between future local market

\footnotetext{
${ }^{8}$ The detailed table of CVR statistics across geographic regions is available upon request.
} 
Equity-Fund Returns

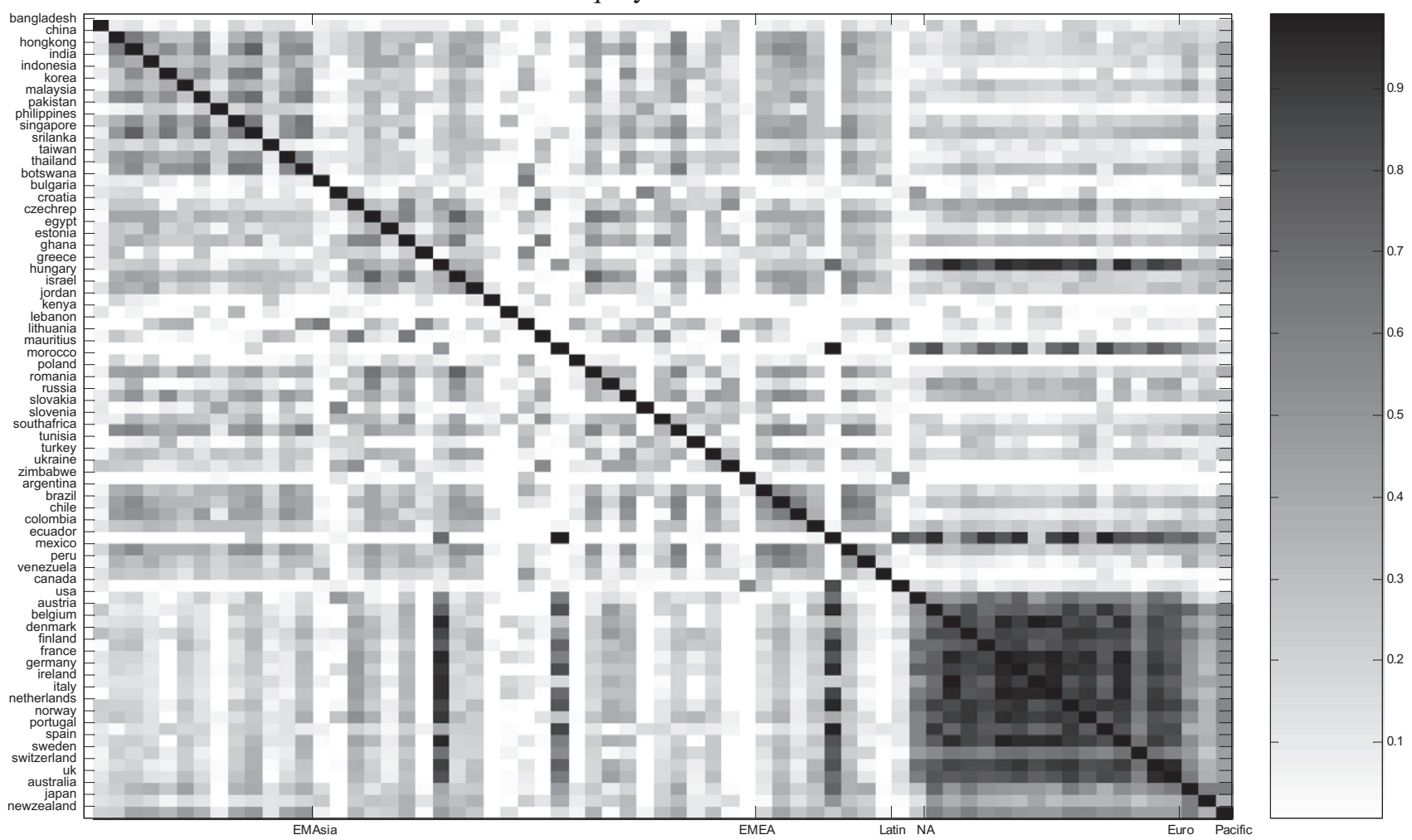

Equity-Fund Net Inflows

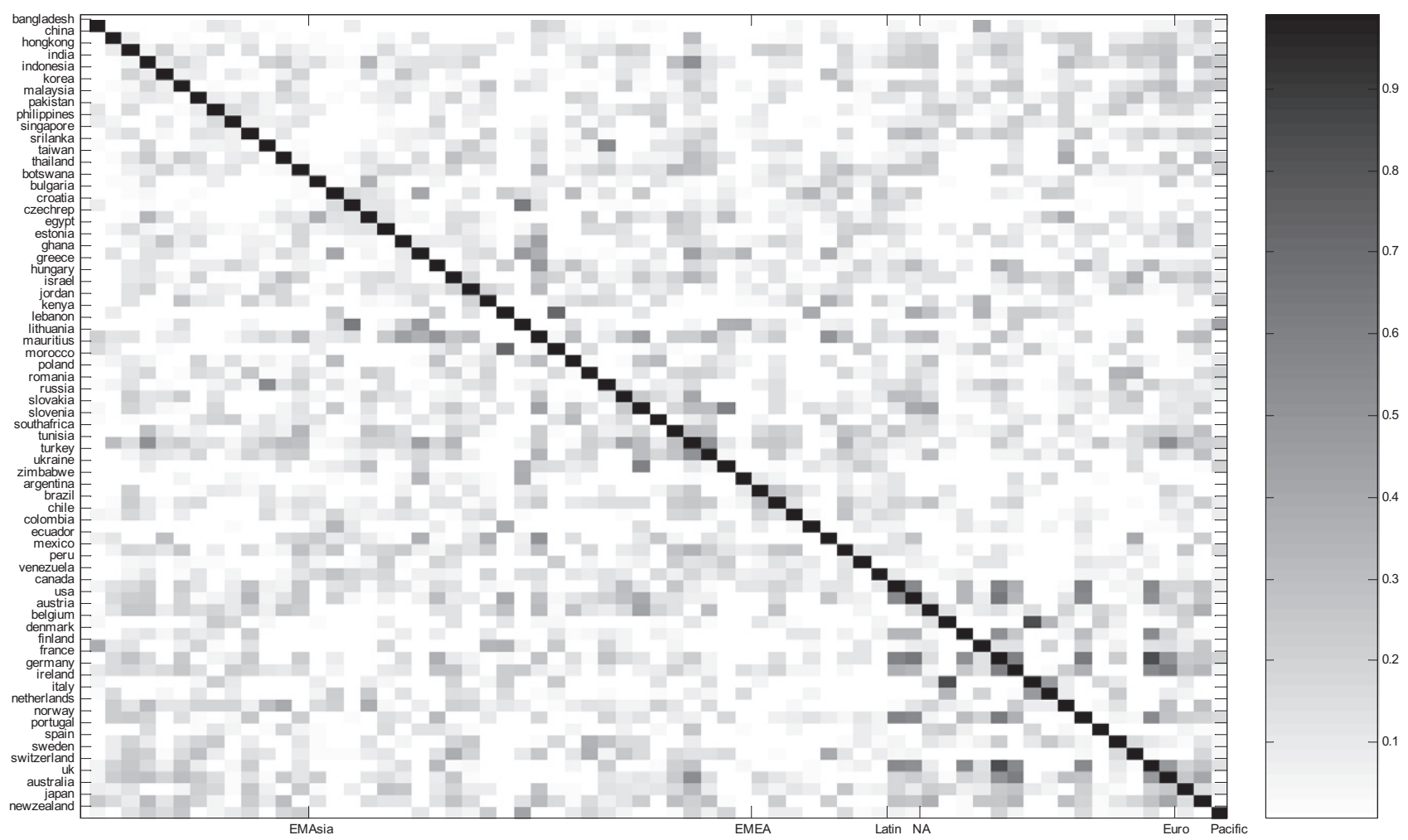

Fig. 1a. Heatmap of monthly equity-fund returns and net inflows. The figure plots pair-wise correlations of equity-fund returns (top panel) and equity-fund net inflows (bottom panel). The sample period is March 1995 to November 2008, derived from the EPFR Global.

returns and current net inflows (lead effects). Further, the lag effects are mostly positive across regions, with the exception of the
Pacific and Latin America regions in the case of equity investment and the emerging markets in Asia in the case of bond investment. 
Bond-Fund Returns

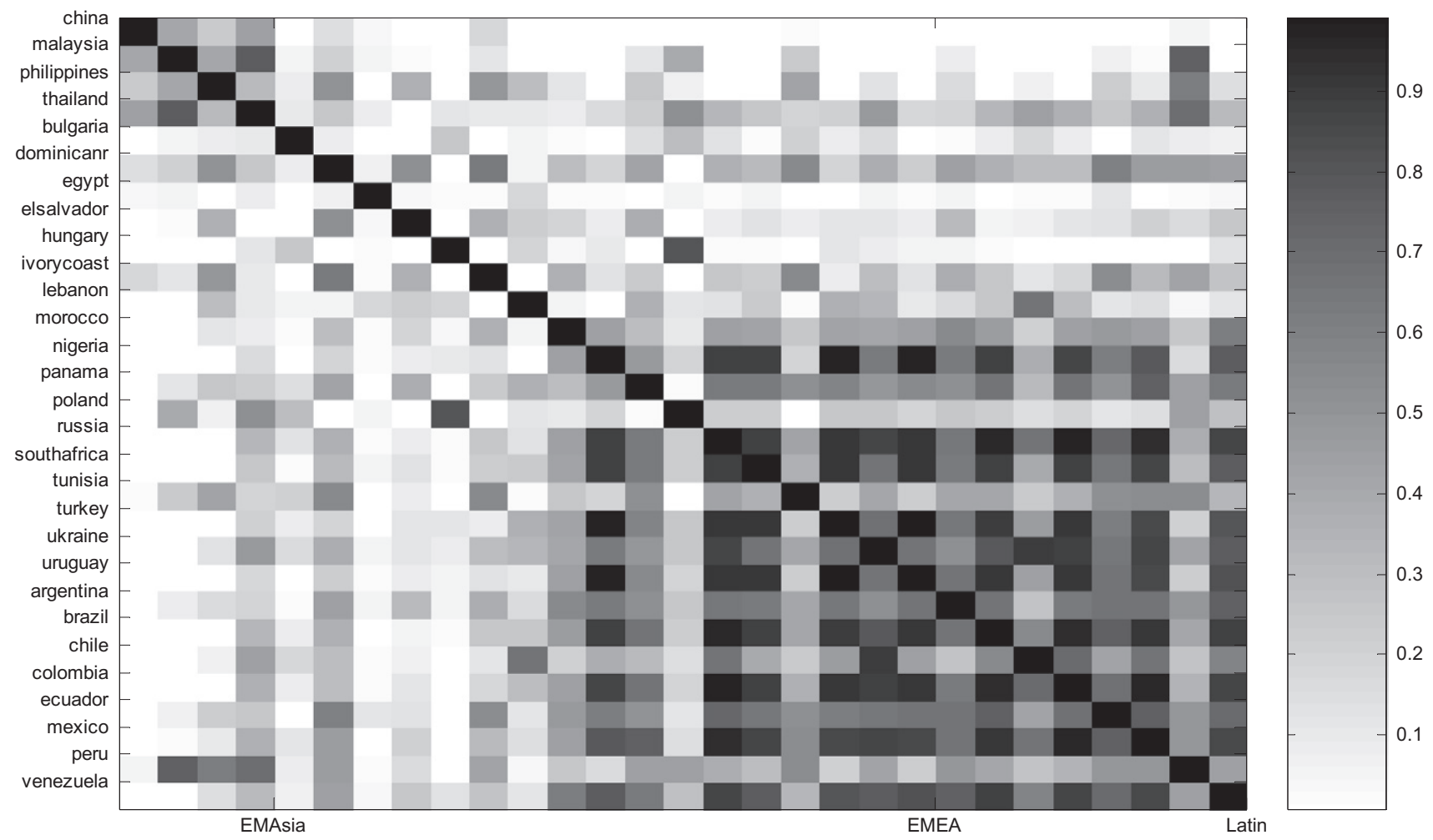

Bond-Fund Net Inflows

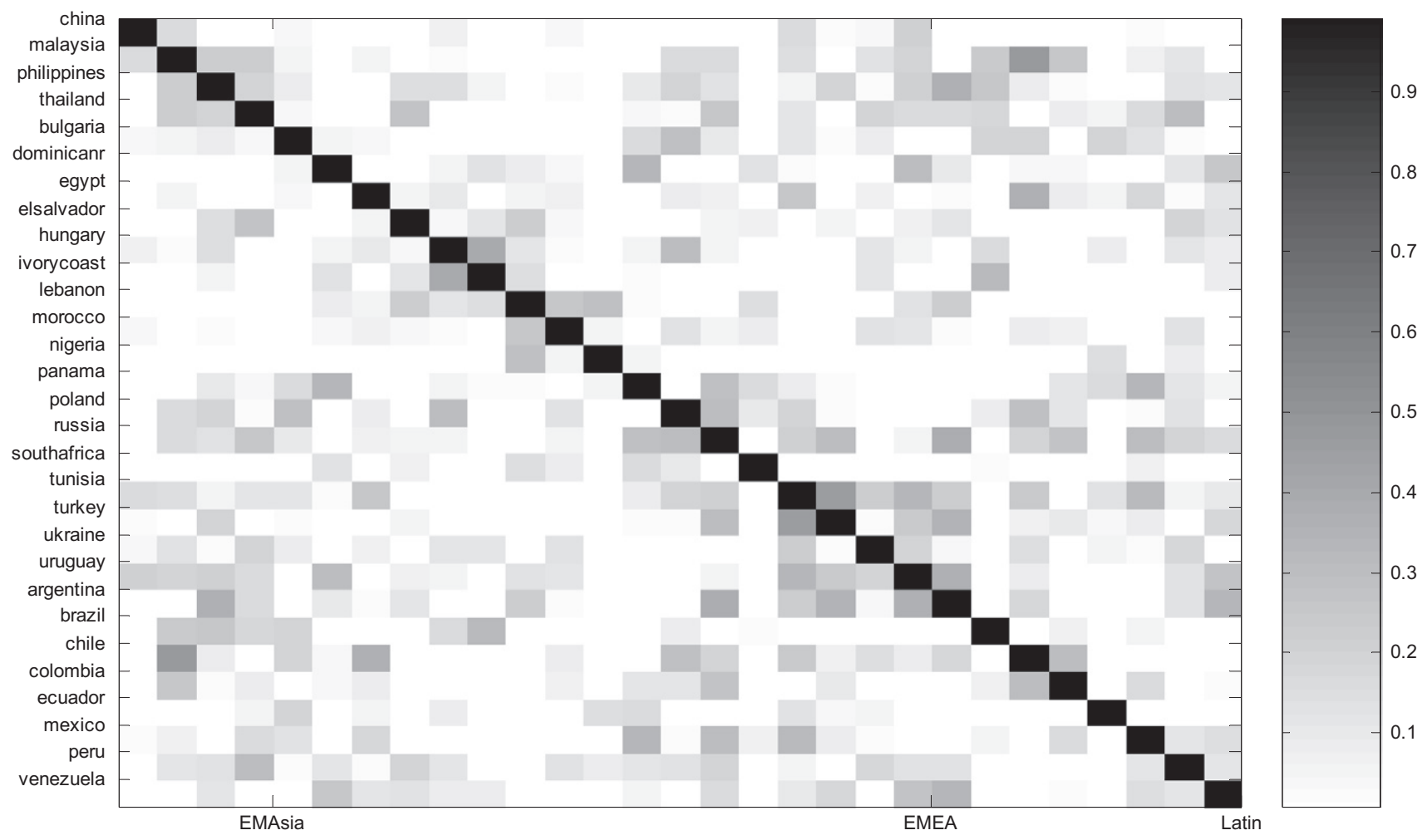

Fig. 1b. Heatmap of monthly bond-fund returns and net inflows. The figure plots pair-wise correlations of bond-fund returns (top panel) and bond-fund net inflows (bottom panel). The sample period is January 2004 to June 2008, derived from the EPFR Global.

This preliminary evidence suggests that the current net inflows are more associated with past returns than they are with future returns. The negative lead effects provide some weak evidence of overreaction. The evidence of positive lag effects largely dominating the comovements between net inflows and local market returns is supportive to the positive feedback and smart money 


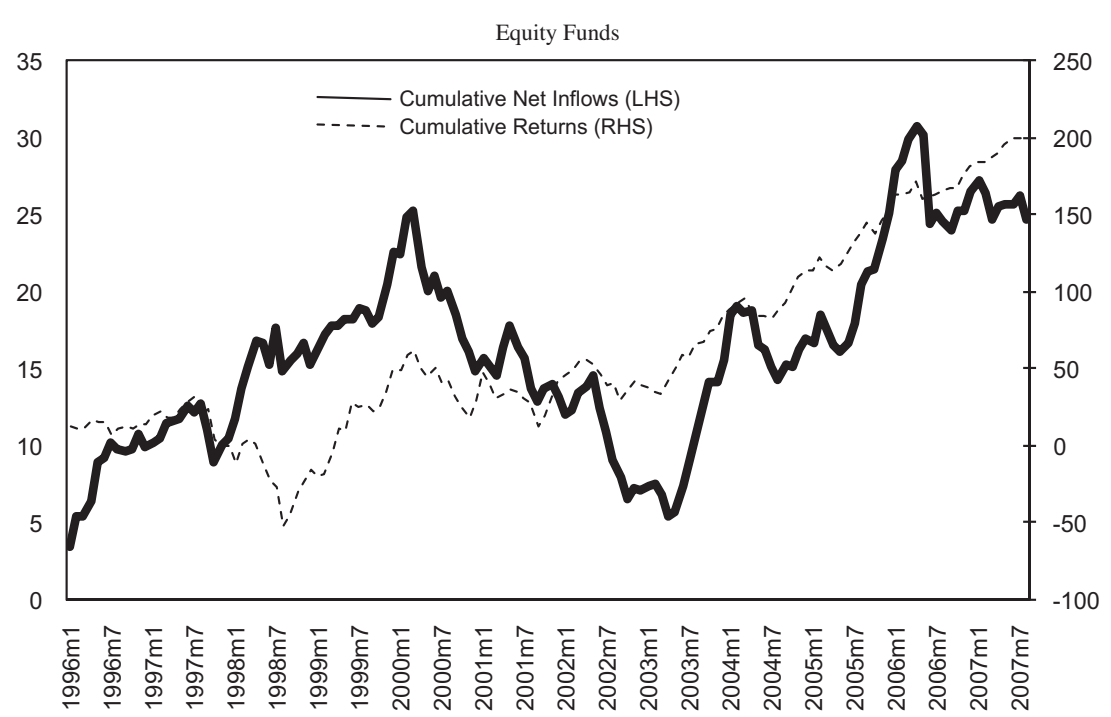

Fig. 2. Detrended cumulative net inflows and returns: emerging-market equity investment. This figure plots detrended cumulative net inflows (purchases minus sales, scaled by total asset holdings) and cumulative returns (percentages). The data are derived from monthly EPFR global.

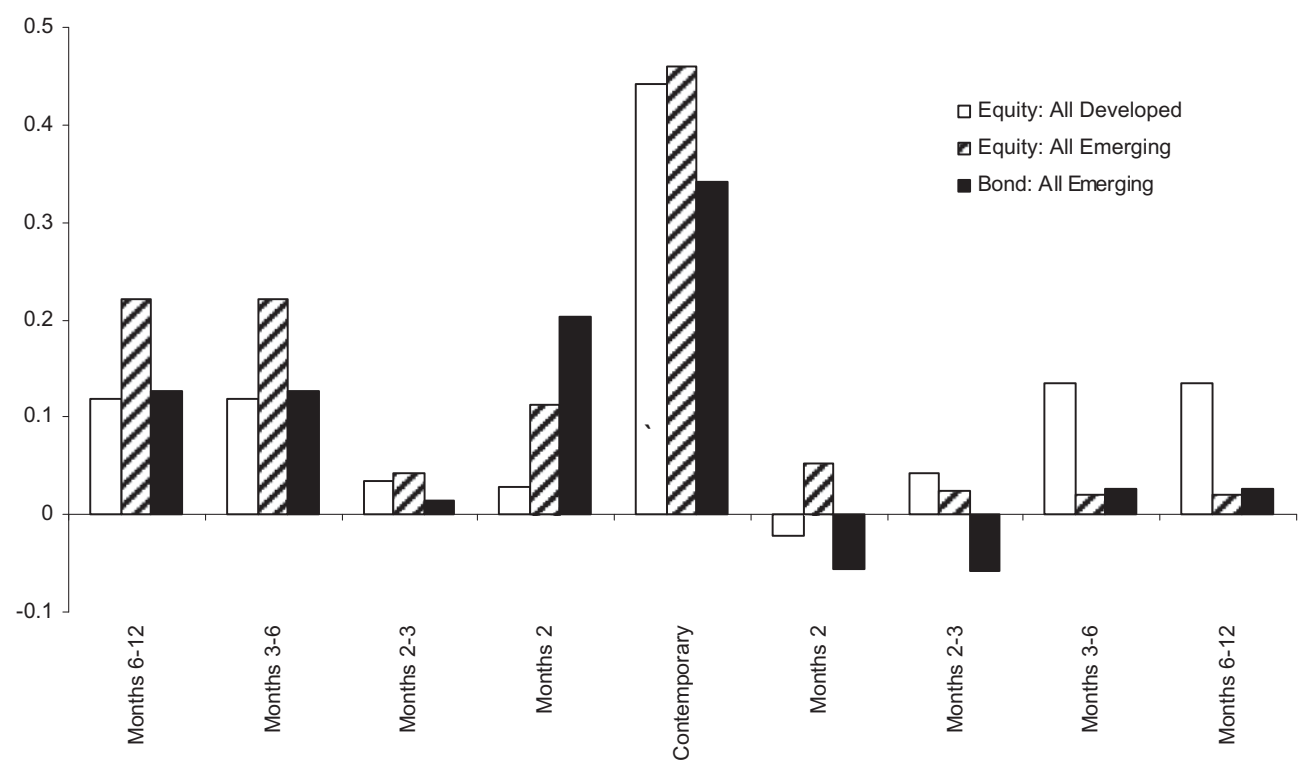

Fig. 3. 12-Month covariance decomposition: net inflows and returns. This figure shows the decomposition (percentages) of the covariance ratio statistic (CVR) for 12-month returns against 12-month net inflows: $C V R_{i}^{k}=\sum_{j=1}^{k-1}\left(1-\frac{j}{k}\right) \beta\left(r_{i, t-j}, f_{i, t}\right)+\beta\left(r_{i, t}, f_{i, t}\right)+\sum_{j=1}^{k-1}\left(1-\frac{j}{k}\right) \beta\left(r_{i, t+j}, f_{i, t}\right)$ (weighted by net inflows of each country within the region). The sample is March 1995 to June 2008 for equity investment, and January 2004 to January 2008 for bond investment, derived from EPFR Global.

hypotheses. ${ }^{9}$ Note that in developed and emerging markets the international fund investment in equities is marginally characterized by a positive association between future returns and current net inflows. Thus, these findings are not entirely supportive to the hypothesis that international investors have cumulative information disadvantage, ${ }^{10}$ at least in our sample of international bond and equity-fund investors.

\section{Measuring interactions between international fund investment and local market returns}

To systematically summarize the comovements between net inflows and local market returns, we now apply vector autoregres-

\footnotetext{
9 See, for example, Keswani and Stolin (2008), and Sapp and Tiwari (2004).

${ }^{10}$ Brennan and Cao (1997) argue in favor of this hypothesis based on their findings in the sample of aggregate US equity flows.
}

sive representation (VAR) to regional aggregate series and then panel VAR to country-level data. The VAR on regional net inflows and market returns allows us to understand how international investment towards the region affects the regional market returns, and vice versa, taking into consideration the regional comovements suggested in Fig. 1. The panel VAR goes a step further by accounting for the interactions between local market returns and net inflows at the country level and therefore taking into consideration both comovements of international investment within the region and the intra-regional investment allocation of the bond and equity funds in our sample.

\subsection{VAR}

Table 3 reports the results from an unrestricted VAR and a structural VAR, using regional aggregates. From the unrestricted VAR: 
Table 3a

VAR estimates. This table summarizes from vector autoregression (VAR) the F-tests for joint significance of lagged returns and lagged flows (the number of lags is 3 months). $\operatorname{corr}\left(e_{1}, e_{2}\right)$ is the contemporaneous correlation between the shocks to flows and the shocks to returns. $T$ denotes the number of observations, and $R$-squared of the two-equation system:

$f_{t}=a_{1}+\sum_{j=1}^{k} \Pi_{11, j} f_{t-j}+\sum_{j=1}^{k} \Pi_{12, j} r_{t-j}+e_{1}$,

$r_{t}=a_{2}+\sum_{j=1}^{k} \Pi_{21, j} f_{t-j}+\sum_{j=1}^{k} \Pi_{22, j} r_{t-j}+e_{2}$

The sample is March 1995 to November 2008 for equity funds (Panel A), and January 2004 to June 2008 for bond funds (Panel B), using regional aggregates of net inflows from the EPFR Global. Fig. 4 provides the cumulative impulse response functions.

\begin{tabular}{|c|c|c|c|c|c|c|c|c|}
\hline & \multicolumn{8}{|c|}{$F$-test for joint significance ( $p$-value show $n$ ) } \\
\hline & $\operatorname{corr}\left(e_{1}, e_{2}\right)$ & $\Pi_{11}$ & $\Pi_{12}$ & $\Pi_{21}$ & $\Pi_{22}$ & $T$ & $R$-squared 1 & $R$-squared 2 \\
\hline \multicolumn{9}{|l|}{ Panel A: Equity funds } \\
\hline All developed & .65 & .58 & .68 & .51 & .55 & 61 & .11 & .15 \\
\hline North America & .36 & .82 & .62 & .01 & .66 & 61 & .12 & .30 \\
\hline Europe & .59 & .07 & .13 & .81 & .63 & 61 & .21 & .11 \\
\hline Pacific & .22 & .00 & .08 & .00 & .91 & 88 & .40 & .26 \\
\hline All emerging & .58 & .00 & .00 & .36 & .30 & 95 & .37 & .14 \\
\hline Emerging Asia & .37 & .06 & .73 & .03 & .11 & 153 & .12 & .15 \\
\hline Emerging Europe and Middle East & .27 & .06 & .00 & .84 & .99 & 144 & .21 & .03 \\
\hline Latin America & .26 & .02 & .01 & .51 & 1.00 & 153 & .15 & .04 \\
\hline \multicolumn{9}{|l|}{ Panel B: Bond funds } \\
\hline All emerging & .31 & .76 & .01 & .88 & .24 & 50 & .20 & .09 \\
\hline Emerging Asia & -.01 & .15 & .90 & .26 & .82 & 50 & .13 & .10 \\
\hline Emerging Europe and Middle East & .34 & .91 & .76 & .73 & .89 & 50 & .04 & .05 \\
\hline Latin America & .19 & .85 & .01 & .40 & .17 & 50 & .19 & .13 \\
\hline
\end{tabular}

Table 3b

Structural VAR estimates. Below is the summary of coefficients on lagged returns and lagged flows from structural VAR, where $\Pi_{\mathrm{c}}$ represent the contemporaneous effects of flows on returns:

$f_{t}=a_{f}+\sum_{j=1}^{k} \Pi_{11, j} f_{t-j}+\sum_{j=1}^{k} \Pi_{12, j} r_{t-j}+e_{f}$,
$r_{t}=a_{r}+\sum_{j=1}^{k} \Pi_{21, j} f_{t-j}+\sum_{j=1}^{k} \Pi_{22, j} r_{t-j}+\Pi_{c} f_{t}+e_{r}$.

\begin{tabular}{|c|c|c|c|c|c|c|c|c|c|c|c|c|c|}
\hline & \multicolumn{13}{|c|}{ VAR coefficients-using regional aggregates ( $t$ statistics in italics below the $i$ coefficients) } \\
\hline & $\Pi_{11,1}$ & $\Pi_{11,2}$ & $\Pi_{11,3}$ & $\Pi_{12,1}$ & $\Pi_{12,2}$ & $\Pi_{12,3}$ & $\Pi_{21,1}$ & $\Pi_{21,2}$ & $\Pi_{21,3}$ & $\Pi_{22,1}$ & $\Pi_{22,2}$ & $\Pi_{22,3}$ & $\Pi_{\mathrm{c}}$ \\
\hline $\begin{array}{l}\text { Panel A: Equity funds } \\
\text { All developed }\end{array}$ & $\begin{array}{r}.22 \\
1.20\end{array}$ & $\begin{array}{l}.15 \\
.83\end{array}$ & $\begin{array}{r}.21 \\
1.19\end{array}$ & $\begin{array}{l}.01 \\
.34\end{array}$ & $\begin{array}{r}.00 \\
-.02\end{array}$ & $\begin{array}{l}-.02 \\
-.62\end{array}$ & $\begin{array}{l}-.72 \\
-.76\end{array}$ & $\begin{array}{l}.18 \\
.18\end{array}$ & $\begin{array}{l}1.26 \\
1.38\end{array}$ & $\begin{array}{r}.24 \\
1.31\end{array}$ & $\begin{array}{r}.39 \\
2.35\end{array}$ & $\begin{array}{l}-.15 \\
-.87\end{array}$ & $\begin{array}{l}3.37 \\
2.35\end{array}$ \\
\hline North America & $\begin{array}{l}-.08 \\
-.50\end{array}$ & $\begin{array}{l}.07 \\
.43\end{array}$ & $\begin{array}{l}.14 \\
.89\end{array}$ & $\begin{array}{r}.09 \\
1.48\end{array}$ & $\begin{array}{r}.10 \\
1.56\end{array}$ & $\begin{array}{l}-.02 \\
-.24\end{array}$ & $\begin{array}{r}-.78 \\
-2.04\end{array}$ & $\begin{array}{r}.76 \\
1.94\end{array}$ & $\begin{array}{l}.33 \\
.85\end{array}$ & $\begin{array}{l}.07 \\
.43\end{array}$ & $\begin{array}{r}.22 \\
1.41\end{array}$ & $\begin{array}{l}.07 \\
.45\end{array}$ & $\begin{array}{l}\mathbf{1 . 0 1} \\
3.34\end{array}$ \\
\hline Europe & $\begin{array}{r}.47 \\
2.35\end{array}$ & $\begin{array}{l}-.03 \\
-.13\end{array}$ & $\begin{array}{l}.19 \\
.98\end{array}$ & $\begin{array}{r}-.04 \\
-1.66\end{array}$ & $\begin{array}{r}.00 \\
-.15\end{array}$ & $\begin{array}{l}.01 \\
.27\end{array}$ & $\begin{array}{r}1.43 \\
.93\end{array}$ & $\begin{array}{l}-2.37 \\
-1.54\end{array}$ & $\begin{array}{l}2.19 \\
1.50\end{array}$ & $\begin{array}{l}.04 \\
.20\end{array}$ & $\begin{array}{r}.50 \\
2.83\end{array}$ & $\begin{array}{l}-.10 \\
-.50\end{array}$ & $\begin{array}{l}\mathbf{5 . 1 0} \\
6.66\end{array}$ \\
\hline Pacific & $\begin{array}{r}.30 \\
1.91\end{array}$ & $\begin{array}{r}.20 \\
1.27\end{array}$ & $\begin{array}{l}-.05 \\
-.36\end{array}$ & $\begin{array}{r}.10 \\
2.46\end{array}$ & $\begin{array}{l}-.03 \\
-.70\end{array}$ & $\begin{array}{l}.02 \\
.59\end{array}$ & $\begin{array}{l}.06 \\
.11\end{array}$ & $\begin{array}{r}.61 \\
1.10\end{array}$ & $\begin{array}{l}-.11 \\
-.25\end{array}$ & $\begin{array}{r}.29 \\
2.03\end{array}$ & $\begin{array}{l}.02 \\
.17\end{array}$ & $\begin{array}{r}.00 \\
-.01\end{array}$ & $\begin{array}{l}\mathbf{1 . 2 5} \\
2.82\end{array}$ \\
\hline All emerging & $\begin{array}{l}-.09 \\
-.54\end{array}$ & $134^{.19}$ & $\begin{array}{r}.16 \\
1.00\end{array}$ & $\begin{array}{r}.10 \\
3.00\end{array}$ & $\begin{array}{l}-.01 \\
-.18\end{array}$ & $\begin{array}{l}-.02 \\
-.56\end{array}$ & $\begin{array}{r}-.90 \\
-1.08\end{array}$ & $\begin{array}{l}-.21 \\
-.24\end{array}$ & $\begin{array}{r}.83 \\
1.01\end{array}$ & $\begin{array}{r}.36 \\
2.20\end{array}$ & $\begin{array}{r}.25 \\
1.25\end{array}$ & $\begin{array}{l}-.03 \\
-.13\end{array}$ & $\begin{array}{l}\mathbf{2 . 5 7} \\
4.33\end{array}$ \\
\hline Emerging Asia & $\begin{array}{l}.02 \\
.14\end{array}$ & $\begin{array}{l}.07 \\
.41\end{array}$ & $\begin{array}{l}.05 \\
.33\end{array}$ & $\begin{array}{r}.09 \\
2.87\end{array}$ & $\begin{array}{l}.03 \\
.72\end{array}$ & $\begin{array}{r}.00 \\
-.07\end{array}$ & $\begin{array}{l}-.73 \\
-.91\end{array}$ & $\begin{array}{l}-.18 \\
-.21\end{array}$ & $\begin{array}{l}.51 \\
.67\end{array}$ & $\begin{array}{r}.33 \\
2.13\end{array}$ & $\begin{array}{l}.15 \\
.77\end{array}$ & $\begin{array}{l}-.02 \\
-.08\end{array}$ & $\begin{array}{l}\mathbf{2 . 1 7} \\
3.51\end{array}$ \\
\hline Emerging Europe and Middle East & $\begin{array}{l}-.16 \\
-.96\end{array}$ & $\begin{array}{l}-.05 \\
-.32\end{array}$ & $\begin{array}{l}.05 \\
.35\end{array}$ & $\begin{array}{r}.13 \\
3.66\end{array}$ & $\begin{array}{l}.00 \\
.04\end{array}$ & $\begin{array}{l}.02 \\
.33\end{array}$ & $\begin{array}{r}-.93 \\
-7.37\end{array}$ & $\begin{array}{l}-.31 \\
-.41\end{array}$ & $\begin{array}{l}.47 \\
.71\end{array}$ & $\begin{array}{r}.40 \\
2.55\end{array}$ & $\begin{array}{r}.29 \\
1.48\end{array}$ & $\begin{array}{l}.01 \\
.07\end{array}$ & $\begin{array}{l}\mathbf{2 . 1 7} \\
4.25\end{array}$ \\
\hline Latin America & $\begin{array}{l}.02 \\
.15\end{array}$ & $\begin{array}{r}.27 \\
1.96\end{array}$ & $\begin{array}{l}.08 \\
.58\end{array}$ & $\begin{array}{r}.03 \\
1.00\end{array}$ & $\begin{array}{l}-.03 \\
-.87\end{array}$ & $\begin{array}{l}-.02 \\
-.44\end{array}$ & $\begin{array}{l}-.68 \\
-.95\end{array}$ & $\begin{array}{l}-.50 \\
-.77\end{array}$ & $\begin{array}{r}.72 \\
1.08\end{array}$ & $\begin{array}{r}.27 \\
1.83\end{array}$ & $\begin{array}{r}.23 \\
1.46\end{array}$ & $\begin{array}{l}.09 \\
.56\end{array}$ & $\begin{array}{l}\mathbf{1 . 7 5} \\
2.96\end{array}$ \\
\hline $\begin{array}{l}\text { Panel B: Bond funds } \\
\text { All emerging }\end{array}$ & $\begin{array}{r}.21 \\
1.40\end{array}$ & $\begin{array}{l}.02 \\
.15\end{array}$ & $\begin{array}{l}-.02 \\
-.15\end{array}$ & $\begin{array}{r}.26 \\
2.81\end{array}$ & $\begin{array}{r}-.11 \\
-1.10\end{array}$ & $\begin{array}{r}.15 \\
1.55\end{array}$ & $\begin{array}{l}.09 \\
.35\end{array}$ & $\begin{array}{l}.18 \\
.69\end{array}$ & $\begin{array}{l}.24 \\
.94\end{array}$ & $\begin{array}{l}.13 \\
.86\end{array}$ & $\begin{array}{l}-.09 \\
-.54\end{array}$ & $\begin{array}{r}-.20 \\
-1.26\end{array}$ & $\begin{array}{r}.71 \\
3.49\end{array}$ \\
\hline Emerging Asia & $\begin{array}{l}.06 \\
.42\end{array}$ & $\begin{array}{l}-.05 \\
-.36\end{array}$ & $\begin{array}{l}-.01 \\
-.08\end{array}$ & $\begin{array}{r}.34 \\
1.77\end{array}$ & $\begin{array}{l}.03 \\
.16\end{array}$ & $\begin{array}{l}-.01 \\
-.06\end{array}$ & $\begin{array}{l}-.01 \\
-.04\end{array}$ & $\begin{array}{l}-.10 \\
-.93\end{array}$ & $\begin{array}{r}.12 \\
1.10\end{array}$ & $\begin{array}{l}.05 \\
.35\end{array}$ & $\begin{array}{l}-.08 \\
-.56\end{array}$ & $\begin{array}{l}-.03 \\
-.21\end{array}$ & $\begin{array}{l}.06 \\
.58\end{array}$ \\
\hline Emerging Europe and Middle East & $\begin{array}{r}.15 \\
1.00\end{array}$ & $\begin{array}{l}-.05 \\
-.33\end{array}$ & $\begin{array}{l}.0 \\
.61\end{array}$ & $\begin{array}{l}.07 \\
.65\end{array}$ & $\begin{array}{l}-.03 \\
-.32\end{array}$ & $\begin{array}{l}.09 \\
.89\end{array}$ & $\begin{array}{l}.16 \\
.89\end{array}$ & $\begin{array}{l}.04 \\
.16\end{array}$ & $\begin{array}{l}-.18 \\
-.77\end{array}$ & $\begin{array}{l}.05 \\
.30\end{array}$ & $\begin{array}{l}.04 \\
.29\end{array}$ & $\begin{array}{l}-.04 \\
-.23\end{array}$ & $\begin{array}{r}.62 \\
3.39\end{array}$ \\
\hline Latin America & $\begin{array}{r}.14 \\
1.02\end{array}$ & $\begin{array}{l}.12 \\
.77\end{array}$ & $\begin{array}{l}-.13 \\
-.89\end{array}$ & $\begin{array}{r}.24 \\
2.91\end{array}$ & $\begin{array}{r}-.09 \\
-1.07\end{array}$ & $\begin{array}{r}.19 \\
2.10\end{array}$ & $\begin{array}{l}.07 \\
.29\end{array}$ & $\begin{array}{l}.20 \\
.79\end{array}$ & $\begin{array}{r}.39 \\
1.53\end{array}$ & $\begin{array}{l}.15 \\
9.7\end{array}$ & $\begin{array}{l}-.11 \\
-.75\end{array}$ & $\begin{array}{r}-.18 \\
-1.21\end{array}$ & $\begin{array}{r}.59 \\
2.72\end{array}$ \\
\hline
\end{tabular}


Unexpected $1 \mathrm{bp}$ shock to flows $\quad$ Unexpected $1 \mathrm{bp}$ shock to returns Developed Markets
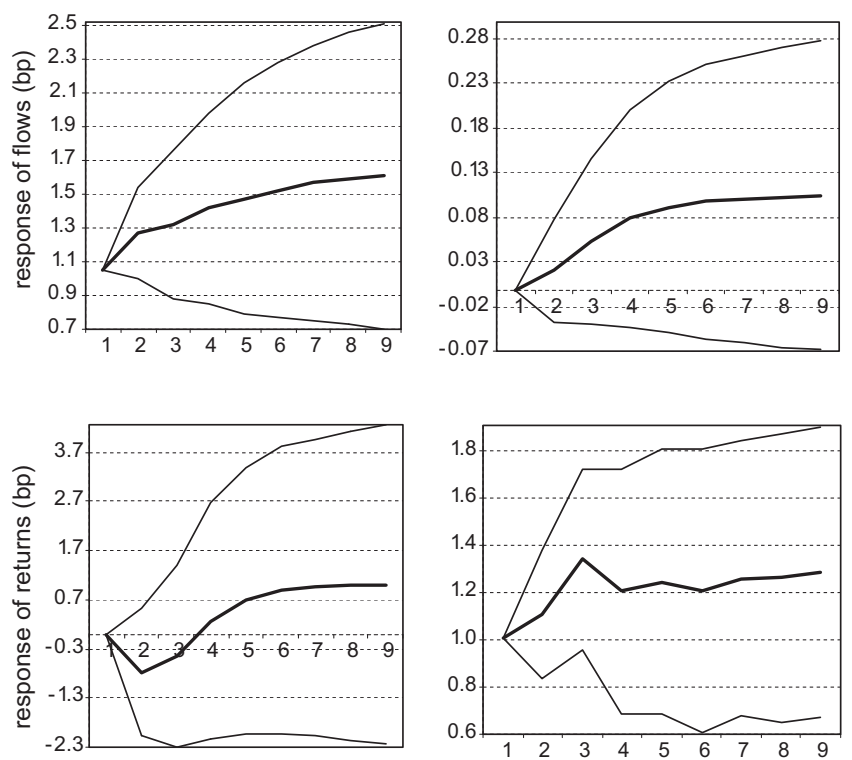

Emerging market Asia
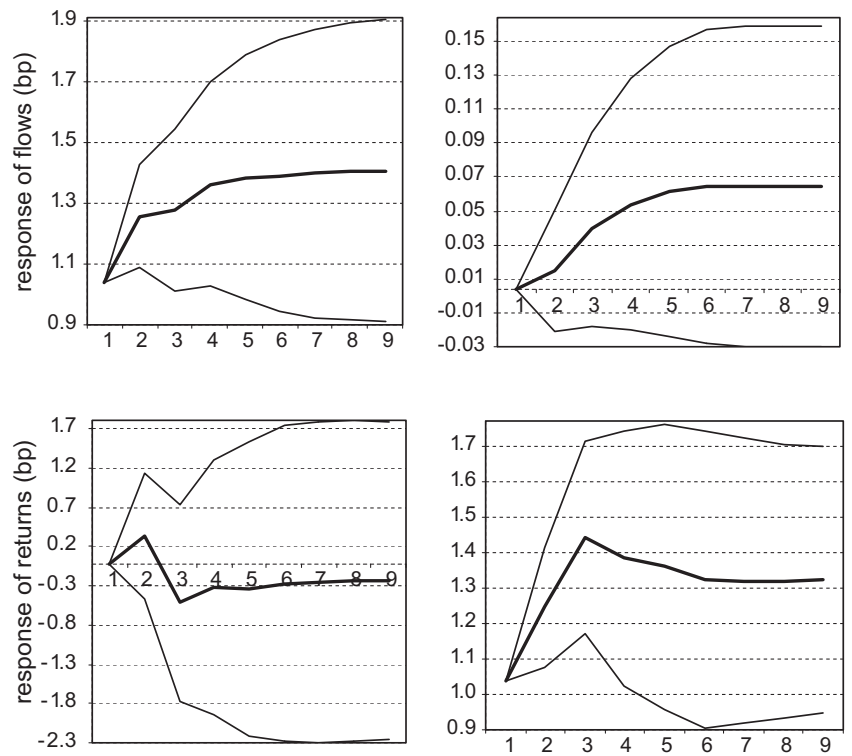

Unexpected $1 \mathrm{bp}$ shock to flows Unexpected $1 \mathrm{bp}$ shock to returns North America
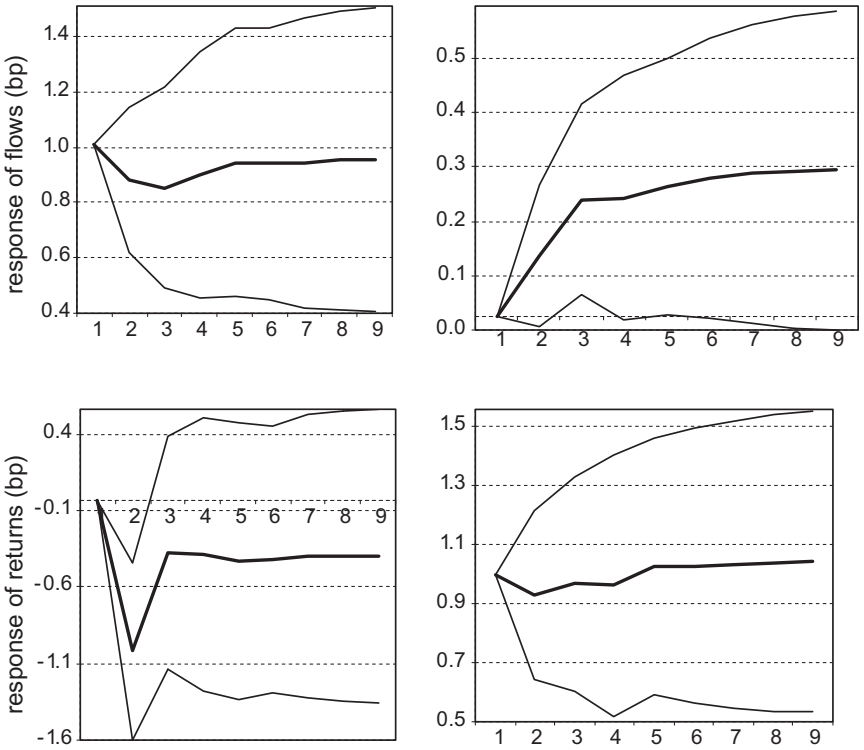

Latin America
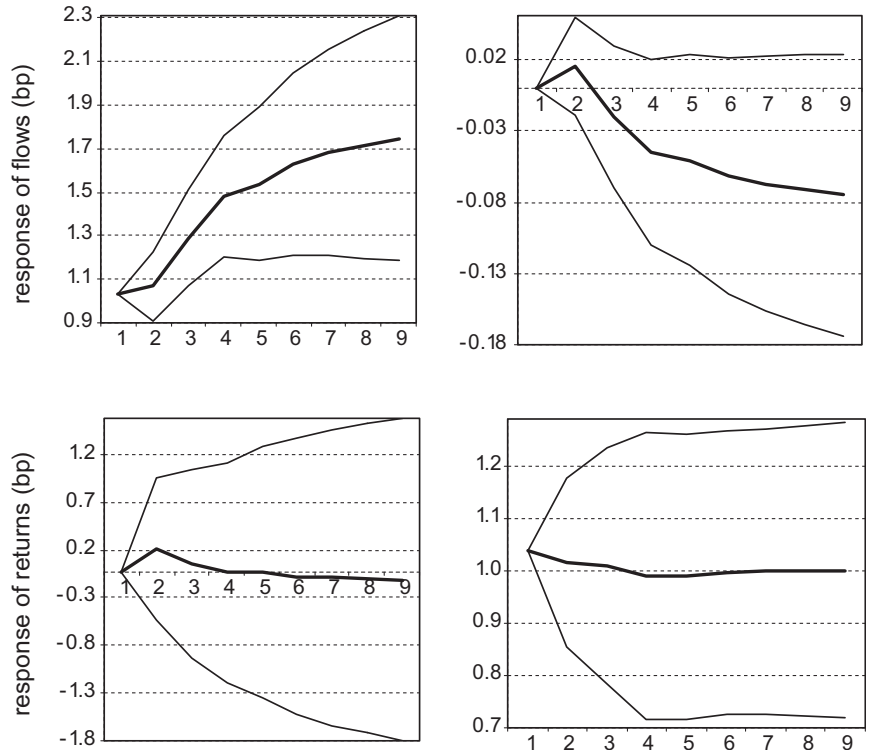

Fig. 4a. Cumulative impulse response - equity investment. This figure plots the cumulative impulse response functions (IRF) of net inflows and returns based on the VAR estimation in Table 3a. Each impulse response is derived from shocking either flows or returns, while holding the other variable constant. The IRF are shown with $90 \%$ confidence intervals.

$$
\begin{aligned}
& f_{t}=a_{1}+\sum_{j=1}^{k} \Pi_{11, j} f_{t-j}+\sum_{j=1}^{k} \Pi_{12, j} r_{t-j}+e_{1}, \\
& r_{t}=a_{2}+\sum_{j=1}^{k} \Pi_{21, j} f_{t-j}+\sum_{j=1}^{k} \Pi_{22, j} r_{t-j}+e_{2} .
\end{aligned}
$$

Table 3a provides the contemporaneous correlation coefficient between the shocks to flows and shocks to returns, $\operatorname{corr}\left(e_{1}, e_{2}\right)$ and the $F$-tests for the joint significance of lagged returns and the joint significance of lagged flows, with the number of lags at $k=3$ months (e.g., the join significance of $\Pi_{21}$ suggests that the past values of net inflows contain useful information in forecasting the current values of local market returns). For the international fund investment in equities, the results show that past net inflows contain information of current net inflows $\left(\Pi_{11}\right)$ in the advanced Pacific and emerging markets. ${ }^{11}$ Furthermore, past local market returns contain information of current net inflows $\left(\Pi_{12}\right)$ in emerging markets, specifically those in Europe and the Middle East and in Latin America. In addition, past net inflows contain information on current local market returns $\left(\Pi_{21}\right)$ in North America and the Pacific markets. For international fund investment in emerging-market bonds, past market returns contain information of net inflows, particularly in Latin America. Note that the correlation coefficients between shocks to returns and shocks to flows, $\operatorname{corr}\left(e_{1}, e_{2}\right)$ are

\footnotetext{
11 Richards (2005) finds from 1999-2002 evidence of price impacts associated with foreigners' trading in Asian emerging equity markets (Indonesia, Korea, Philippines, Taiwan, and Thailand). We do not find this to be the case in our sample.
} 
positive and that the $R$-squared in most cases are small, suggesting that a significant portion of the interactions between net inflows and local market returns is still largely unexplained by the unrestricted VAR.

Fig. 4a provides the cumulative impulse response functions for the equity investment. A shock of one basis point to net inflows increases subsequent net inflows over the next 6 months by 1.5 basis points in the developed markets, 0.9 basis points in North America, 1.4 basis points in emerging markets in Asia, and 1.6 basis points in Latin America. A shock of one basis point to local market returns increases subsequent market returns over the next six months by 1.2 basis points in the developed markets, 1 basis point in North America, 1.3 basis points in emerging markets in Asia, and 1 basis point in Latin America. A shock of one basis point to net inflows decreases the local market returns in North America by 1 basis point during the first three months: the price-pressure response in North America seems to be the only convincing evidence from the unrestricted $V A R$ of equity investment.
Fig. 4b provides the cumulative impulse response functions for the emerging-market bond investment. A shock of one basis point to net inflows increases subsequent net inflows over the next six months by 0.9 basis points for all emerging markets, 0.7 basis points in Asia, 1 basis point in Europe and the Middle East, and 0.9 basis points in Latin America. A shock of one basis point to local market returns increases subsequent market returns over the next 6 months by 0.8 basis points for all emerging markets, 0.8 basis points in Asia, 0.9 basis points in Europe and the Middle East, and 0.8 basis points in Latin America. A shock of one basis point to local market returns increases during the first four months the net inflows to the overall emerging markets by 0.2 basis points and particularly those to Latin America by 0.25 basis points, suggesting the positive-feedback trading in these bond markets.

Given that our 12-month CVR decompositions show that the contemporaneous effects account for the majority of comovements between net inflows and local market returns, it is therefore useful to gauge the contemporaneous effect in a structural VAR framework. Following Froot et al. (2001) the price impact of unexpected
Unexpected $1 \mathrm{bp}$ shock to flows Unexpected $1 \mathrm{bp}$ shock to returns Emerging markets
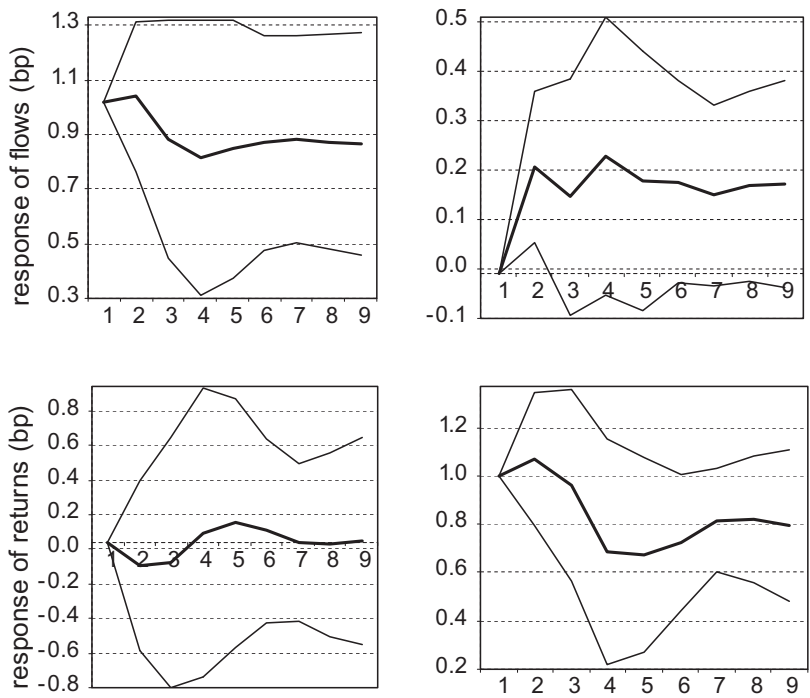

Emerging market Europeandthe Middle East
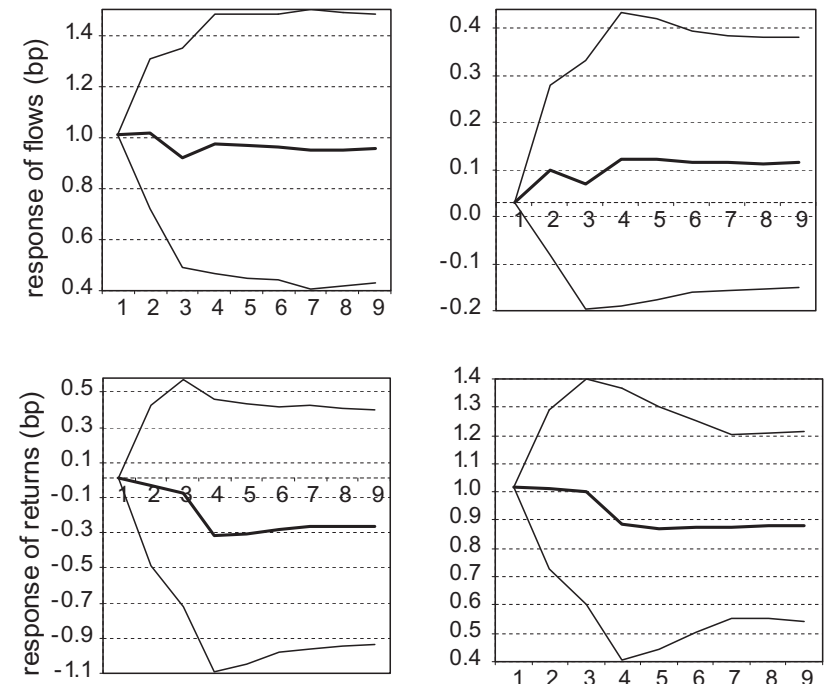

Unexpected $1 \mathrm{bp}$ shock to flows Unexpected $1 \mathrm{bp}$ shock to returns Emerging market Asia
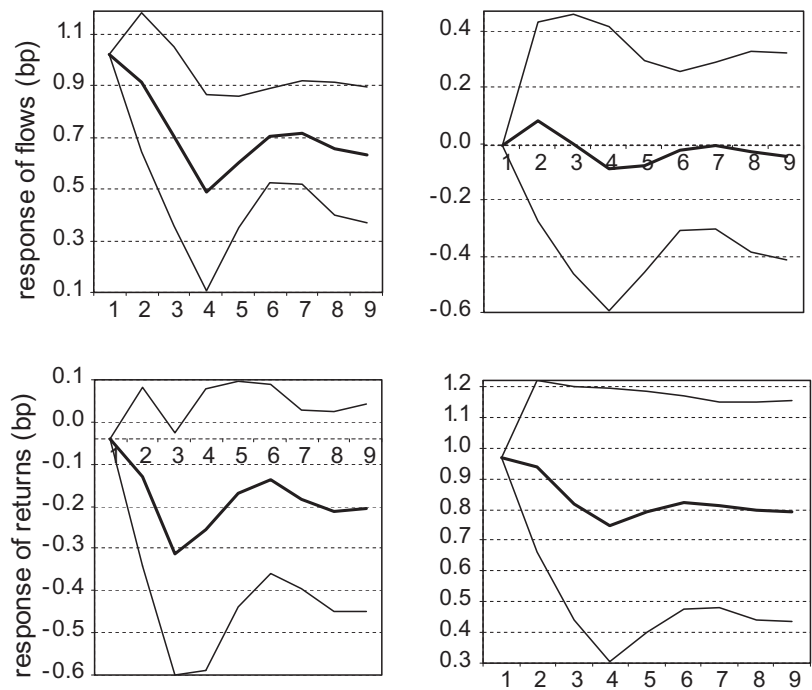

Latin America
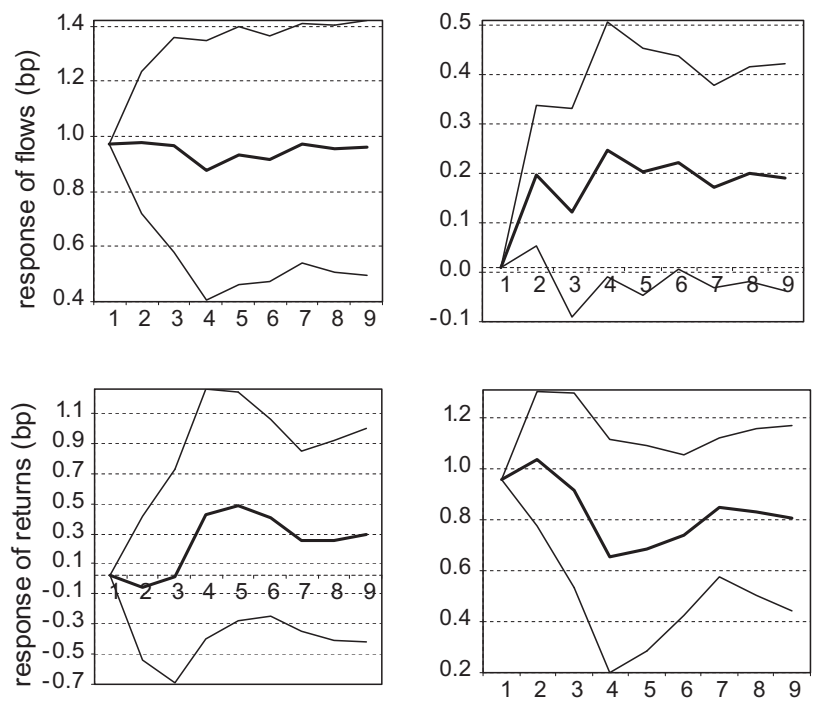

Fig. 4b. Cumulative impulse response - bond investment. 
Table 4a

Panel VAR estimates. This table summarizes from panel vector autoregression (VAR) the F-tests for joint significance of lagged returns and lagged flows (the number of lags is 3 months). corr $\left(e_{1}, e_{2}\right)$ is the contemporaneous correlation between the shocks to flows and the shocks to returns. $T$ denotes the number of observations, and $R$-squared of the twoequation system:

$f_{i, t}=a_{f i}+\sum_{j=1}^{k} \Pi_{11, j} f_{i, t-j}+\sum_{j=1}^{k} \Pi_{12, j} r_{i, t-j}+e_{f i, t}$,

$r_{i, t}=a_{r i}+\sum_{j=1}^{k} \Pi_{21, j} f_{i, t-j}+\sum_{j=1}^{k} \Pi_{22, j} r_{i, t-j}+e_{r i, t}$.

The sample is March 1995 to November 2008 for equity funds (Panel A), and January 2004 to June 2008 for bond funds (Panel B), using country-level data of net inflows from the EPFR Global.

\begin{tabular}{|c|c|c|c|c|c|c|c|c|}
\hline & \multicolumn{8}{|c|}{$F$-test for joint significance ( $p$-value show $n$ ) } \\
\hline & $\operatorname{corr}\left(e_{1}, e_{2}\right)$ & $\Pi_{11}$ & $\Pi_{12}$ & $\Pi_{21}$ & $\Pi_{22}$ & $T$ & $R$-squared 1 & $R$-squared 2 \\
\hline \multicolumn{9}{|l|}{ Panel A: Equity funds } \\
\hline All developed & -.07 & .00 & .41 & .72 & .00 & 1100 & .04 & .05 \\
\hline North America & .14 & .75 & .94 & .62 & .69 & 110 & .03 & .04 \\
\hline Europe & -.11 & .01 & .65 & .63 & .00 & 825 & .03 & .06 \\
\hline Pacific & .13 & .02 & .25 & .51 & .00 & 165 & .13 & .11 \\
\hline All emerging & -.06 & .49 & .06 & .10 & .40 & 2272 & .04 & .03 \\
\hline Emerging Asia & .00 & .95 & .00 & .29 & .00 & 715 & .11 & .06 \\
\hline Emerging Europe and Middle East & -.06 & .70 & .29 & .33 & .67 & 1155 & .04 & .03 \\
\hline Latin America & -.15 & .01 & .48 & .36 & .60 & 402 & .08 & .02 \\
\hline \multicolumn{9}{|l|}{ Panel B: Bond funds } \\
\hline All emerging & .02 & .32 & .84 & .96 & .00 & 1894 & .02 & .02 \\
\hline Emerging Asia & -.01 & .00 & .72 & .36 & .94 & 220 & .17 & .02 \\
\hline Emerging Europe and Middle East & .00 & .74 & .66 & .98 & .00 & 904 & .02 & .03 \\
\hline Latin America & .13 & .17 & .99 & .04 & .00 & 440 & .03 & .09 \\
\hline
\end{tabular}

net inflows on local market returns is represented by the coefficient $\Pi_{c}$ in the following system:

$$
\begin{aligned}
f_{t} & =a_{f}+\sum_{j=1}^{k} \Pi_{11, j} f_{t-j}+\sum_{j=1}^{k} \Pi_{12, j} r_{t-j}+e_{f}, \\
r_{t} & =a_{r}+\sum_{j=1}^{k} \Pi_{21, j} f_{t-j}+\sum_{j=1}^{k} \Pi_{22, j} r_{t-j}+\Pi_{c} f_{t}+e_{r} .
\end{aligned}
$$

Table $3 \mathrm{~b}$ report the coefficient estimates and corresponding $t$ statistics, with the number of lags set to 3 months. We can see that $\Pi_{c}$ is all positive and statistically significant (the only exception being bond investment in Asian emerging market). For equity investment in emerging markets, the estimate suggests that a positive shock to net inflows equal to one basis point results in a contemporaneous increase in local market returns of 2.57 basis points. The corresponding coefficient for developed markets is 3.37 basis points. ${ }^{12}$ Overall, the contemporaneous effects of net inflows on local market returns are large and statistically significant across regional groups in the case of international fund investment in both bonds and equities. The estimates of $\Pi_{12}$, the impact of lagged local market returns on net inflows, are positive for developed Pacific and emerging markets: temporary appreciation in local market returns results in temporary net inflows. This structural VAR suggests, consistent with the CVR statistics, that while past local market returns forecast net inflows positively, a significant part of comovements of flows and returns is associated with the contemporaneous effect. $^{13}$

\footnotetext{
${ }^{12}$ We also estimate another structural VAR, replacing contemporaneous net inflows with contemporaneous local market returns in the flow equation, and reach the same conclusion.

${ }^{13}$ Our results for equity investment are different from Froot et al. (2001), who, using daily equity flow data, find that temporary inflows drive temporary price decreases. However, they do point out that this does not mean that inflows negatively forecast returns, since the inflows are persistent.
}

\subsection{Panel VAR}

Using regional series in the VAR implicitly assumes that countries of the same region are nearly homogenous in terms of flowreturn relationships. While countries within a region relate more closely to each other than to countries in other regions, as shown in the heatmaps of Fig. 1, it is useful to check whether country-specific characteristics affect the flow-return relationships, using a panel VAR with the country-level data.

The joint significance tests of panel VAR estimates reported in Table 4a are quite different from our earlier exercise using regional aggregates (Table 3a). First, the correlations of residuals, $\operatorname{corr}\left(e_{1}\right.$, $e_{2}$ ), decrease significantly, suggesting that the panel VAR does a better job (than the unrestricted VAR with regional series) in summarizing the net inflow-local return associations. Second, the evidence of flow persistence in emerging-markets is no longer significant. Third, while previous results from VAR with regional series show no evidence of return persistence across regions and samples, results from panel VAR find supportive evidence in developed markets (Europe and Pacific) and emerging markets in Asia for equity investment and for emerging-market bond investment in general (except Asia). Fourth, the evidence of positive-feedback trading survives only for the case of equity investment in emerging markets in Asia.

Table $4 \mathrm{~b}$ provides the estimates from structural panel VAR. The contemporary effect of net inflows on returns, $\Pi_{c}$, is statistically significant, though it has become negative (over-reaction of markets to international flows) and relatively smaller in absolute size than that of the structural VAR with regional series. The evidence of positive feedback trading, $\Pi_{12}$, is significant only for equity investment in emerging markets (particularly Asia). This result suggests that country-specific characteristics influence the estimates of contemporaneous flow-return relations in a significant way. For the case of equity investment, it suggests that a positive shock to inflows equal to one basis point of capitalization results in a contemporaneous decrease in prices of $0.1-0.27$ basis points.

The estimated impact of lagged net inflow on returns, $\Pi_{21}$, is significant and negative for equity investment in emerging mar- 
Table 4b

Structural panel VAR estimates. Below is the summary of coefficients on lagged returns and lagged flows from structural panel VAR, where $\Pi_{c}$ represent the contemporaneous effects of flows on returns:

$f_{i, t}=a_{f i}+\sum_{j=1}^{k} \Pi_{11, j} f_{i, t-j}+\sum_{j=1}^{k} \Pi_{12, j} r_{i, t-j}+e_{f i, t}$,

$r_{i, t}=a_{r i}+\sum_{j=1}^{k} \Pi_{21, j} f_{i, t-j}+\sum_{j=1}^{k} \Pi_{22, j} r_{i, t-j}+e_{r i, t}$.

Reported below are the average coefficients, calculated as $\frac{1}{k}=\sum_{j=1}^{k} \Pi_{* j, j}$.

\begin{tabular}{|c|c|c|c|c|c|c|c|c|c|c|c|c|c|}
\hline & \multicolumn{13}{|c|}{ Panel VAR coefficients averaged across countries in region ( $t$-statistics in italics below the coefficients) } \\
\hline & $\Pi_{11,1}$ & $\Pi_{11,2}$ & $\Pi_{11,3}$ & $\Pi_{12,1}$ & $\Pi_{12,2}$ & $\Pi_{12,3}$ & $\Pi_{21,1}$ & $\Pi_{21,2}$ & $\Pi_{21,3}$ & $\Pi_{22,1}$ & $\Pi_{22,2}$ & $\Pi_{22,3}$ & $\Pi_{\mathrm{c}}$ \\
\hline $\begin{array}{l}\text { Panel A: Equity funds } \\
\text { All developed }\end{array}$ & $\begin{array}{r}.12 \\
3.92\end{array}$ & $\begin{array}{l}.01 \\
.34\end{array}$ & $\begin{array}{l}-.01 \\
-.25\end{array}$ & $\begin{array}{r}.02 \\
1.55\end{array}$ & $\begin{array}{l}.00 \\
.28\end{array}$ & $\begin{array}{l}.00 \\
.24\end{array}$ & $\begin{array}{l}-.02 \\
-.19\end{array}$ & $\begin{array}{l}-.02 \\
-.23\end{array}$ & $\begin{array}{r}.09 \\
1.14\end{array}$ & $\begin{array}{r}.12 \\
3.97\end{array}$ & $\begin{array}{r}.17 \\
5.39\end{array}$ & $\begin{array}{r}-.04 \\
-1.20\end{array}$ & $\begin{array}{r}-.20 \\
-2.48\end{array}$ \\
\hline North America & $\begin{array}{l}.00 \\
.04\end{array}$ & $\begin{array}{l}.02 \\
.22\end{array}$ & $\begin{array}{r}.11 \\
1.07\end{array}$ & $\begin{array}{l}.01 \\
.55\end{array}$ & $\begin{array}{l}.01 \\
.35\end{array}$ & $\begin{array}{r}.00 \\
-.01\end{array}$ & $\begin{array}{l}.04 \\
.10\end{array}$ & $\begin{array}{l}.40 \\
.94\end{array}$ & $\begin{array}{l}-.40 \\
-.94\end{array}$ & $\begin{array}{l}-.03 \\
-.26\end{array}$ & $\begin{array}{l}-.01 \\
-.14\end{array}$ & $\begin{array}{r}-.12 \\
-1.19\end{array}$ & $\begin{array}{r}.61 \\
1.52\end{array}$ \\
\hline Europe & $\begin{array}{r}.12 \\
3.25\end{array}$ & $\begin{array}{l}.00 \\
.06\end{array}$ & $\begin{array}{l}-.01 \\
-.21\end{array}$ & $\begin{array}{r}.02 \\
1.18\end{array}$ & $\begin{array}{l}.00 \\
.11\end{array}$ & $\begin{array}{l}.00 \\
.20\end{array}$ & $\begin{array}{l}-.01 \\
-.07\end{array}$ & $\begin{array}{l}-.04 \\
-.43\end{array}$ & $\begin{array}{r}.12 \\
1.28\end{array}$ & $\begin{array}{r}. \mathbf{1 4} \\
3.81\end{array}$ & $\begin{array}{r}.19 \\
5.18\end{array}$ & $\begin{array}{l}-.03 \\
-.90\end{array}$ & $\begin{array}{r}-.27 \\
-3.03\end{array}$ \\
\hline Pacific & $\begin{array}{r}.22 \\
2.72\end{array}$ & $\begin{array}{r}.09 \\
1.03\end{array}$ & $\begin{array}{r}-.11 \\
-1.34\end{array}$ & $\begin{array}{r}.10 \\
1.93\end{array}$ & $\begin{array}{r}.00 \\
-.03\end{array}$ & $\begin{array}{l}.02 \\
.34\end{array}$ & $\begin{array}{l}-.10 \\
-.81\end{array}$ & $\begin{array}{l}.02 \\
.14\end{array}$ & $\begin{array}{r}.16 \\
1.31\end{array}$ & $\begin{array}{r}.24 \\
3.10\end{array}$ & $\begin{array}{r}.12 \\
1.56\end{array}$ & $\begin{array}{l}.04 \\
.47\end{array}$ & $\begin{array}{r}.20 \\
1.67\end{array}$ \\
\hline All Emerging & $\begin{array}{r}.00 \\
-.18\end{array}$ & $\begin{array}{r}-.03 \\
-1.53\end{array}$ & $\begin{array}{l}-.01 \\
-.35\end{array}$ & $\begin{array}{r}.00 \\
-.32\end{array}$ & $\begin{array}{l}.00 \\
.44\end{array}$ & $\begin{array}{r}.02 \\
2.66\end{array}$ & $\begin{array}{l}-.03 \\
-.69\end{array}$ & $\begin{array}{r}-.09 \\
-2.42\end{array}$ & $\begin{array}{l}-.01 \\
-.28\end{array}$ & $\begin{array}{r}-.02 \\
-1.09\end{array}$ & $\begin{array}{r}-.02 \\
-1.26\end{array}$ & $\begin{array}{l}-.01 \\
-.78\end{array}$ & $\begin{array}{r}-.10 \\
-2.82\end{array}$ \\
\hline Emerging Asia & $\begin{array}{l}.01 \\
.60\end{array}$ & $\begin{array}{r}.00 \\
-.13\end{array}$ & $\begin{array}{r}.00 \\
-.08\end{array}$ & $\begin{array}{r}.15 \\
4.85\end{array}$ & $\begin{array}{l}.03 \\
.90\end{array}$ & $\begin{array}{r}.06 \\
1.63\end{array}$ & $\begin{array}{l}.01 \\
.36\end{array}$ & $\begin{array}{r}.05 \\
1.85\end{array}$ & $\begin{array}{l}.01 \\
.34\end{array}$ & $\begin{array}{r}.20 \\
5.21\end{array}$ & $\begin{array}{l}.02 \\
.36\end{array}$ & $\begin{array}{r}.09 \\
2.13\end{array}$ & $\begin{array}{r}.00 \\
-.03\end{array}$ \\
\hline Emerging Europe and Middle East & $\begin{array}{r}.00 \\
-.11\end{array}$ & $\begin{array}{r}-.04 \\
-1.15\end{array}$ & $\begin{array}{l}-.01 \\
-.35\end{array}$ & $\begin{array}{r}.00 \\
-.26\end{array}$ & $\begin{array}{l}.00 \\
.30\end{array}$ & $\begin{array}{r}.02 \\
1.89\end{array}$ & $\begin{array}{l}-.03 \\
-.51\end{array}$ & $\begin{array}{r}-.09 \\
-1.78\end{array}$ & $\begin{array}{l}-.01 \\
-.20\end{array}$ & $\begin{array}{l}-.02 \\
-.80\end{array}$ & $\begin{array}{l}-.02 \\
-.91\end{array}$ & $\begin{array}{l}-.01 \\
-.57\end{array}$ & $\begin{array}{r}-.10 \\
-2.01\end{array}$ \\
\hline Latin America & $\begin{array}{r}-.08 \\
-1.53\end{array}$ & $\begin{array}{r}.06 \\
1.21\end{array}$ & $\begin{array}{r}.17 \\
3.00\end{array}$ & $\begin{array}{r}.10 \\
1.54\end{array}$ & $\begin{array}{l}.01 \\
.25\end{array}$ & $\begin{array}{l}.01 \\
.32\end{array}$ & $\begin{array}{l}-.01 \\
-.17\end{array}$ & $\begin{array}{l}.02 \\
.60\end{array}$ & $\begin{array}{r}-.07 \\
-1.64\end{array}$ & $\begin{array}{r}.05 \\
1.06\end{array}$ & $\begin{array}{l}-.01 \\
-.52\end{array}$ & $\begin{array}{l}.02 \\
.62\end{array}$ & $\begin{array}{r}-.12 \\
-3.10\end{array}$ \\
\hline $\begin{array}{l}\text { Panel B: Bond funds } \\
\text { All Emerging }\end{array}$ & $\begin{array}{l}-.02 \\
-.92\end{array}$ & $\begin{array}{l}-.02 \\
-.81\end{array}$ & $\begin{array}{l}-.02 \\
-.86\end{array}$ & $\begin{array}{l}.04 \\
.15\end{array}$ & $\begin{array}{l}.02 \\
.08\end{array}$ & $\begin{array}{l}.05 \\
.16\end{array}$ & $\begin{array}{r}.00 \\
-.52\end{array}$ & $\begin{array}{l}.00 \\
.21\end{array}$ & $\begin{array}{l}.00 \\
.00\end{array}$ & $\begin{array}{l}.01 \\
.36\end{array}$ & $\begin{array}{r}-.07 \\
-2.71\end{array}$ & $\begin{array}{r}-.06 \\
-2.39\end{array}$ & $\begin{array}{l}.00 \\
.12\end{array}$ \\
\hline Emerging Asia & $\begin{array}{r}-.16 \\
-2.29\end{array}$ & $\begin{array}{r}.32 \\
4.90\end{array}$ & $\begin{array}{l}.01 \\
.07\end{array}$ & $\begin{array}{r}.08 \\
1.06\end{array}$ & $\begin{array}{l}-.03 \\
-.38\end{array}$ & $\begin{array}{l}-.02 \\
-.29\end{array}$ & $\begin{array}{r}-.11 \\
-1.74\end{array}$ & $\begin{array}{l}-.04 \\
-.62\end{array}$ & $\begin{array}{l}.01 \\
.20\end{array}$ & $\begin{array}{l}-.02 \\
-.25\end{array}$ & $\begin{array}{l}-.01 \\
-.19\end{array}$ & $\begin{array}{l}-.04 \\
-.54\end{array}$ & $\begin{array}{l}-.01 \\
-.08\end{array}$ \\
\hline Emerging Europe and Middle East & $\begin{array}{l}-.02 \\
-.68\end{array}$ & $\begin{array}{l}-.02 \\
-.67\end{array}$ & $\begin{array}{l}-.02 \\
-.64\end{array}$ & $\begin{array}{l}.05 \\
.09\end{array}$ & $\begin{array}{l}.10 \\
.18\end{array}$ & $\begin{array}{l}.12 \\
.21\end{array}$ & $\begin{array}{r}.00 \\
-.39\end{array}$ & $\begin{array}{l}.00 \\
.21\end{array}$ & $\begin{array}{l}.00 \\
.06\end{array}$ & $\begin{array}{l}-.01 \\
-.16\end{array}$ & $\begin{array}{r}-.13 \\
-3.62\end{array}$ & $\begin{array}{r}-.07 \\
-1.84\end{array}$ & $\begin{array}{l}.00 \\
.00\end{array}$ \\
\hline Latin America & $\begin{array}{r}.09 \\
1.89\end{array}$ & $\begin{array}{l}-.03 \\
-.61\end{array}$ & $\begin{array}{r}.06 \\
1.27\end{array}$ & $\begin{array}{l}.01 \\
.22\end{array}$ & $\begin{array}{r}-.08 \\
-1.19\end{array}$ & $\begin{array}{l}-.02 \\
-.31\end{array}$ & $\begin{array}{l}.01 \\
.22\end{array}$ & $\begin{array}{r}.11 \\
2.65\end{array}$ & $\begin{array}{r}-.05 \\
-1.17\end{array}$ & $\begin{array}{r}.15 \\
3.00\end{array}$ & $\begin{array}{r}-.11 \\
-2.03\end{array}$ & $\begin{array}{r}-.19 \\
-3.23\end{array}$ & $\begin{array}{r}.11 \\
2.79\end{array}$ \\
\hline
\end{tabular}

kets, while it is positive for bond investment in Latin America. These findings suggest that temporary inflows result in temporary price declines in the former and increases in the latter. Because inflows are highly persistent series, this does not imply that inflows forecast returns negatively for equity investment in emerging markets (or, for the same reason, positively for bond investment in Latin America). The implication from this panel VAR estimation is the difference in the impact of foreign inflows on local market returns between equity investment and bond investment in emerging markets.

\section{Comovements of international equity and bond investment}

Our analysis so far points to potential benefits of taking into account the comovement of the bond and equity investments of international fund investors. The comovement may provide an empirical measure of the diversification gains associated with diversifying across country portfolios and across asset classes. By and large, the examination of the relationship between regional and country-specific factors with the inclusion of international bond investment can be considered as a natural next step to better understanding international asset price correlations. Our exploration of the interaction between international bond and equity flows and returns therefore contributes to the major strand of the literature on the relationship between regional and specific country factors in the international return comovements (see Bekaert et al., 2009).

Earlier studies on the comovements of bond and equity prices, e.g., Campbell and Ammer (1993) for the US, focus on countryspecific experiences. Hong et al. (2009) find in the cases of Canada, Germany, Japan, the UK and the US that the correlations between stock and bond returns are related to the size of the financial market and the growth and volatility of the economy. ${ }^{14}$ Does the interaction between flows and returns differ across bond and equity-fund markets? The existing literature provides a mixed guidance on this issue. Brennan and Aranda (1999) show that due to information asymmetry during the Asian crisis, the proportional change of foreign bondholdings in an economy in response to a change in that economy's economic prospects was greater than the proportional change in foreign stockholdings. Chuhan et al. (1998) find that equity flows are more sensitive than bond flows to global factors but that bond flows are generally more sensitive to a country's credit rating and secondary market debt price. ${ }^{15}$

\footnotetext{
14 For all the five countries, they find the correlation is positive for the 1986-1999 period and negative for the 2000-2007 periods. See also Panchenko and Wu (2009) for a case of 18 emerging markets, Yang et al. (2009) for a long-run correlation, and Forte and Peña (2009) with the addition of CDS.

15 The issue is further complicated by a possible pecking order and financial market development, as documented in recent studies, i.e., Daude and Fratzscher (2008).
} 
Table 5a

Comparison of equity and bond investment - panel VAR. This table reports the coefficient estimates ( $p$-values in italics below the coefficients) from panel VAR estimation:

$f_{i, t}=a_{f i}+\sum_{j=1}^{k} \Pi_{11, j} f_{i, t-j}+\sum_{j=1}^{k} \Pi_{12, j} r_{i, t-j}+e_{f i, t}$,

$r_{i, t}=a_{r i}+\sum_{j=1}^{k} \Pi_{21, j} f_{i, t}$

The sample is a balanced panel of 17 countries, with 59 monthly observations each, from January 2004 to June 2008 for both the equity and bond investments, using country-level data of net inflows derived from the EPFR Global.

\begin{tabular}{lrrrrrr}
\hline & $f_{-1}$ & $f_{-2}$ & $f_{-3}$ & $r_{-1}$ & $r_{-2}$ & $r_{-3}$ \\
\hline Equity & & & & & & \\
$f$ & -.08 & .00 & .12 & .09 & -.03 & -.02 \\
& .02 & .94 & .00 & .00 & .40 & .66 \\
$r$ & .01 & .05 & -.05 & .12 & -.02 & .06 \\
& .78 & .16 & .22 & .00 & .55 & .11 \\
\multirow{2}{*}{ Bond } & & & & & & \\
$f$ & -.02 & -.02 & -.02 & .04 & .02 & .05 \\
& .47 & .53 & .51 & .92 & .97 & .91 \\
$\boldsymbol{r}$ & .00 & .00 & .00 & .00 & -.03 & -.07 \\
& .69 & .88 & .95 & .92 & .43 & .05 \\
\hline
\end{tabular}

To have a fair benchmark in understanding the dynamics of bond and equity markets, we stratify the sample period for bond and equity investments to be exactly the same: January 2004 to January 2008; as a result, we have a balanced panel of 17 countries, with 59 monthly observations each. We first explore a difference between the dynamics of bond and equity investment using panel $V A R$ with country-level series. The empirical specification can be written as

$$
\begin{aligned}
f_{i, t} & =a_{f i}+\sum_{j=1}^{k} \Pi_{11, j} f_{i, t-j}+\sum_{j=1}^{k} \Pi_{12, j} r_{i, t-j}+e_{f i, t} \\
r_{i, t} & =a_{r i}+\sum_{j=1}^{k} \Pi_{21, j} f_{i, t-j}+\sum_{j=1}^{k} \Pi_{22, j} r_{i, t-j}+e_{r i, t},
\end{aligned}
$$

for $i=1, \ldots, 17$, and where $a_{f i}$ and $a_{r i}$ is the country-specific constant. $\Pi_{x y, j}(x=1,2 ; y=1,2 ; j=1, \ldots, k)$ is the parameter to be estimated, which is constrained to be the same across countries. According to the CVR statistics, we set $k=3$, and include returns and flows in the past three months (a quarter) in our estimation.

Table $5 a$ presents the coefficient estimates and their $p$-values from panel VAR of equity investment (top panel) and bond investment (bottom panel). Regarding the conditional momentum in flows and returns of $\Pi_{11, j}$ and $\Pi_{22, j}(j=1, \ldots, k)$, the forecasting power of past inflows on current inflows is higher in equity investment than it is in bond investment. We next analyze the conditional feedback between flows and returns from $\Pi_{12, j}$ and $\Pi_{21, j}$ $(j=1, \ldots, k)$. For the equity investment, the results of $\Pi_{12, j}$ suggest that current net inflows are positively associated with past local market returns for equity investment (a 10\% increase in past local market returns raises current equity net inflows by $1 \%$ ), which is supportive to the positive feedback trading hypothesis by international investors. ${ }^{16}$ For the bond investment, the results are constrained by a stratified sample (too small to uncover the dynamics at regional level) and the power of the statistical tests is lower. Regarding the effects of past net inflows on current returns, $\Pi_{21, j}$, the results show no support for the hypothesis that flows contain

16 See, for example, Froot et al. (2001), Froot and Ramadorai (2008a), and Kaminsky et al. (2004) private information for future returns or that flows generate price pressure in both the bond and equity investments.

As neither past net inflows nor past local market returns could explain net inflows to the international bond investment, we are left with the question of what drives the net inflows. There are practically two sources of net inflows: new money and capital reallocation. New money that flows into international funds goes either to bond funds, equity funds or a combination of both, which could result in interdependence of net flows into the bond and equity investments. ${ }^{17}$ Generally, within the mutual fund, investors tend to reallocate their money from equity to bond funds when there is a negative shock on equity markets, and vice versa (e.g., Chordia et al., 2005): the asset reallocation between equity and bond funds means a negative correlation between equity and bond net inflows. Thus, the association between bond and equity net inflows depends on the effect of new money relative to the effect of asset reallocation.

To account for interdependence of the bond and equity investments, we first check the sample correlations between equity net inflows and bond net inflows and find that they are all negative. As widely documented in the literature, equity returns and bond returns tend to be negatively correlated. However, the existing literature have offered no evidence on whether net inflows and returns of equity investment affect bond flows and returns of international fund investors. To address this question, we estimate the interdependence using the panel VAR method:

$$
\begin{aligned}
B f_{i, t}= & a_{B f i}+\sum_{j=1}^{k} \Pi_{11, j} B f_{i, t-j}+\sum_{j=1}^{k} \Pi_{12, j} B r_{i, t-j}+\sum_{j=1}^{k} \Pi_{13, j} E f_{i, t-j} \\
& +\sum_{j=1}^{k} \Pi_{14, j} E r_{i, t-j}+e_{B f, t}, \\
B r_{i, t}= & a_{B r i}+\sum_{j=1}^{k} \Pi_{21, j} B f_{i, t-j}+\sum_{j=1}^{k} \Pi_{22, j} B r_{i, t-j}+\sum_{j=1}^{k} \Pi_{23, j} E f_{i, t-j} \\
& +\sum_{j=1}^{k} \Pi_{24, j} E r_{i, t-j}+e_{B r i, t}, \\
E f_{i, t}= & a_{E f i}+\sum_{j=1}^{k} \Pi_{31, j} B f_{i, t-j}+\sum_{j=1}^{k} \Pi_{32, j} B r_{i, t-j}+\sum_{j=1}^{k} \Pi_{33, j} E f_{i, t-j} \\
& +\sum_{j=1}^{k} \Pi_{34, j} E r_{i, t-j}+e_{E f i, t}, \\
E r_{i, t}= & a_{E r i}+\sum_{j=1}^{k} \Pi_{41, j} B f_{i, t-j}+\sum_{j=1}^{k} \Pi_{42, j} B r_{i, t-j}+\sum_{j=1}^{k} \Pi_{43, j} E f_{i, t-j} \\
& +\sum_{j=1}^{k} \Pi_{44, j} E r_{i, t-j}+e_{E r i, t},
\end{aligned}
$$

where $B f, B r, E f$ and $E r$ represent bond flows, bond returns, equity flows and equity returns, respectively.

The bond-equity panel VAR results are presented in Table 5b. For equity investment, the evidence of flow and return persistence as well as positive feedback trading remains significant in the panel estimation. The panel estimation has low explanatory power on the bond investment (longer lags, e.g., $k=6$, provide similar results). Interestingly, we can see that the response of equity returns to past bond flows is positive and statistically significant (onemonth lag). Furthermore, the effect of past equity returns on current bond flows is also significant (three-month lag).

\footnotetext{
17 Given a limited or leveraged position, more investment in equity funds would result in less capital flow to the bond funds: these results in a negative correlation between changes in bond and equity flows. On the other hand, if the new money increases the asset holdings of both equity and bond funds (not just one of them), this means a positive correlation between bond and equity flows.
} 
Table 5b

Comovements of equity and bond investment - panel VAR. Below are the coefficient estimates ( $p$-values in italics below the coefficients) from panel VAR estimation:

$B f_{i, t}=a_{B f i}+\sum_{j=1}^{k} \Pi_{11, j} B f_{i, t-j}+\sum_{j=1}^{k} \Pi_{12, j} B r_{i, t-j}+\sum_{j=1}^{k} \Pi_{13, j} E f_{i, t-j}+\sum_{j=1}^{k} \Pi_{14, j} E r_{i, t-j}+e_{B f, t}$,

$B r_{i, t}=a_{B r i}+\sum_{j=1}^{k} \Pi_{21, j} B f_{i, t-j}+\sum_{j=1}^{k} \Pi_{22, j} B r_{i, t-j}+\sum_{j=1}^{k} \Pi_{23, j} E f_{i, t-j}+\sum_{j=1}^{k} \Pi_{24, j} E r_{i, t-j}+e_{B r i, t}$,

$E f_{i, t}=a_{E f i}+\sum_{j=1}^{k} \Pi_{31, j} B f_{i, t-j}+\sum_{j=1}^{k} \Pi_{32, j} B r_{i, t-j}+\sum_{j=1}^{k} \Pi_{33, j} E f_{i, t-j}+\sum_{j=1}^{k} \Pi_{34, j} E r_{i, t-j}+e_{E f i, t}$,

$E r_{i, t}=a_{E r i}+\sum_{j=1}^{k} \Pi_{41, j} B f_{i, t-j}+\sum_{j=1}^{k} \Pi_{42, j} B r_{i, t-j}+u m_{j=1}^{k} \Pi_{43, j} E f_{i, t-j}+\sum_{j=1}^{k} \Pi_{44, j} E r_{i, t-j}+e_{E r i, t}$.

The sample period is the same as Table $5 \mathrm{a}$.

\begin{tabular}{|c|c|c|c|c|c|c|c|c|c|c|c|c|}
\hline & $B f_{-1}$ & $B f_{-2}$ & $B f_{-3}$ & $B r_{-1}$ & $\mathrm{Br}_{-2}$ & $\mathrm{Br}_{-3}$ & $E f_{-1}$ & $E f_{-2}$ & $E f_{-3}$ & $E r_{-1}$ & $E r_{-2}$ & $E r_{-3}$ \\
\hline \multirow[t]{2}{*}{ Ef } & .00 & .00 & .00 & .01 & -.01 & .00 & -.08 & .00 & .12 & .10 & -.03 & -.02 \\
\hline & .70 & .75 & .33 & .62 & .43 & .95 & .02 & .37 & .00 & .00 & .37 & .65 \\
\hline \multirow[t]{2}{*}{$\mathrm{Er}$} & .01 & .00 & .00 & .04 & .03 & .02 & .01 & .05 & -.05 & .11 & -.03 & .06 \\
\hline & .00 & .71 & .69 & .08 & .19 & .29 & .83 & .17 & .24 & .00 & .48 & .14 \\
\hline \multirow[t]{2}{*}{$\mathrm{Bf}$} & -.03 & -.02 & -.03 & .03 & -.01 & -.03 & .18 & -.28 & -1.28 & -.01 & .93 & 1.97 \\
\hline & .41 & .53 & .37 & .95 & .98 & .96 & .83 & .73 & .14 & .98 & .25 & .02 \\
\hline \multirow[t]{2}{*}{$\mathrm{Br}$} & .00 & .00 & .00 & -.01 & -.03 & -.07 & -.02 & -.05 & -.03 & .07 & -.02 & -.10 \\
\hline & .70 & .99 & .99 & .78 & .41 & .05 & .79 & .40 & .69 & .20 & .80 & .12 \\
\hline
\end{tabular}

One possible explanation is that the capital gains from equity investment are reallocated to bond investment for risk diversification. For example, in a portfolio exposed to both equity and bond investment, if, due to capital gains, the asset based in equity investment grows so fast that it exceeds the desired proportion, investors may consider rebalancing the portfolio by transferring to (or investing new money in) bond investment. This possibility is in line with the portfolio rebalancing model of Hau and Rey (2006). Note that the effect of past bond flows on equity returns is positive and operating with one-month lag, while the effect of past equity returns on bond flows is positive and operating with three-month lag. It is plausible that equity returns are more sensitive to private information, global factors, macroeconomic news and interest rates that tend to have a greater impact on bond flows (i.e., the proportional change of foreign bondholdings in an economy in response to a change in that economy's economic prospects was greater than the proportional change in foreign stockholdings Brennan and Aranda, 1999). The positive response of bond flows to past equity returns suggests the effect of capital gains on bond investment (i.e., through portfolio-rebalancing) that operates at three-month lag, which could be due to portfolio decision on the bond-equity reallocation that is likely to happen at quarterly frequency.

Overall, taking into consideration the interactions between bond and equity investment, our evidence suggests that past equity returns contain useful information in current equity and bond flows and that past bond flows help to forecast current equity returns. The international fund investors in our sample, while not strongly pursuing potentially destabilizing trading practices, do not simply react on a delayed basis to news publicly available in the underlying bond and equity markets. While future availability of longer data at higher frequency should increase the statistical power of our estimation, we find that accounting for the interdependence of bond and equity markets aids the uncovering of the true dynamics of local market returns and investment by international investors.

\section{Conclusion}

Do net inflows of international investors help to forecast the local market returns, and vice versa? We have provided new evi- dence based on equity and bond investment by international funds. Unlike most previous studies that only focus on the flowreturn association in the equity markets, we distinguish the dynamics at the regional and country levels, and we allow for the interactions between bond and equity investment.

We plan to further study (with higher frequency and more details, fund-level data) the interactions between the flow-return relationship in the bond and equity markets. Several fruitful directions will include disentangling the driving factors (global, regional, and country-specific), understanding the comovements of bond and equity flows, the dynamics of flows and returns within a country or region, and the role of liquidity and default risks on the international fund investment.

While in this paper we focus on measuring the interactions between net inflows and local market returns, the results have broader implications. For example, the finding that temporary appreciation in local equity returns results in temporary net inflows (local market returns forecast net inflows positively) in both bond and equity investments can be a useful input for international portfolio models aiming to rationalize the behavior of domestic and international investors and understand the dynamics lies at the intersection of macroeconomics and finance. ${ }^{18}$

\section{Acknowledgements}

We would like to thank an anonymous reviewer, Chayawadee Chai-anant, Iwan Meier, and participants at the Australasian Finance \& Banking Conference 2009 in Sydney and the Thammasat University/Japan Bank for International Cooperation Conference on the Future of Economic Integration in Asia 2008 in Bangkok. Ngo Dieu Thuy Trang provided excellent research assistance. The views expressed in this paper are ours.

\section{References}

Albuquerque, R., Bauer, G.H., 2007. International equity flows and returns: a quantitative equilibrium approach. Review of Economic Studies 74, 1-30.

Aviat, A., Coeurdacier, N., 2007. The geography of trade in goods and asset holdings. Journal of International Economics 71, 22-51.

18 See for example Calvo and Mendoza (2000) and Albuquerque and Bauer (2007). 
Baele, L., Bekaert, G., Inghelbrecht, K., in press. The determinants of stock and bond return comovements. Review of Financial Studies.

Bekaert, G., Harvey, C.R., Lumsdaine, R.L., 2002. The dynamics of emerging market equity flows. Journal of International Money and Finance 21, 295-350.

Bekaert, G., Hodrick, R.J., Zhang, X., 2009. International stock return comovements. Journal of Finance 64, 2591-2626.

Brennan, M.J., Aranda, C., 1999. What makes hot money hot? The relative volatility of international flows of debt and equity capital. Review of Pacific Basin Financial Markets and Policies 2, 427-451.

Brennan, M.J., Cao, H.H., 1997. International portfolio investment flows. Journal of Finance 52, 1851-1880.

Broner, F.A., Gaston Gelos, R., Reinhart, C.M., 2006. When in peril, retrench: testing the portfolio channel of contagion. Journal of International Economics 69, 203230.

Brooks, R., Del Negro, M., 2005. Country versus region effects in international stock returns. Journal of Portfolio Management 31, 67-72.

Calvo, G.A., Mendoza, E.G., 2000. Rational contagion and the globalization of securities markets. Journal of International Economics 51, 79-113.

Campbell, J.Y., Ammer, J., 1993. What moves the stock and bond markets? A variance decomposition for long-term asset returns. Journal of Finance 48, 3-37.

Chan, K., Covrig, V., Ng, L., 2005. What determines the domestic bias and foreign bias? Evidence from mutual fund equity allocations worldwide. Journal of Finance 60, 1495-1534

Chordia, T., Sarkar, A., Subrahmanyam, A., 2005. An empirical analysis of stock and bond market liquidity. Review of Financial Studies 18, 85-129.

Chuhan, P., Claessens, S., Mamingi, N., 1998. Equity and bond flows to Latin America and Asia: the role of global and country factors. Journal of Development Economics 55, 439-463.

Claessens, S., Dooley, M.P., Warner, A., 1995. Portfolio capital flows: hot or cold? World Bank Economic Review 9, 153-174.

Daude, C., Fratzscher, M., 2008. The pecking order of cross-border investment. Journal of International Economics 74, 94-119.

De Santis, R.A., Lührmann, M., 2009. On the determinants of net international portfolio flows: a global perspective. Journal of International Money and Finance 28, 880-901.

Eichengreen, B., 2006. Asian Bond Markets: Issues and Prospects. Bank for International Settlements, Basel, Switzerland.

Ferreira, M.A., Laux, P.A., 2009. Portfolio flows, volatility and growth. Journal of International Money and Finance 28, 271-292.

Forte, S., Peña, J.I., 2009. Credit spreads: an empirical analysis on the informational content of stocks, bonds, and CDS. Journal of Banking and Finance 33, 20132025.

Froot, K.A., O'Connell, P.G.J., Seasholes, M.S., 2001. The portfolio flows of international investors. Journal of Financial Economics 59, 151-193.

Froot, K.A., Ramadorai, T., 2008. Institutional portfolio flows and international investments. Review of Financial Studies 21, 937-971.

Gelos, R.G., Wei, S.-J., 2005. Transparency and international portfolio holdings. Journal of Finance 60, 2987-3020.
Griffin, J.M., Nardari, F., Stulz, R.M., 2004. Are daily cross-border equity flows pushed or pulled? Review of Economics and Statistics 86, 641-657.

Hau, H., Rey, H., 2006. Exchange rates, equity prices, and capital flows. Review of Financial Studies 19, 273-317.

Hau, H., Rey, H., 2008. Home bias at the fund level. American Economic Review 98, 333-338.

Hong, G., Kim, Y., Lee, B.-S., 2009. Correlations between Stock Returns and Bond Returns: Income and Substitution Effects. College of Business, Florida State University.

Kaminsky, G., Lyons, R.K., Schmukler, S.L., 2004. Managers, investors, and crises: mutual fund strategies in emerging markets. Journal of International Economics $64,113-134$

Keswani, A., Stolin, D., 2008. Which money is smart? mutual fund buys and sells of individual and institutional investors. Journal of Finance 63, 85-118.

Lakonishok, J., Shleifer, A., Vishny, R.W., 1992. The impact of institutional trading on stock prices. Journal of Financial Economics 32, 23-43.

Levchenko, A.A., Mauro, P., 2007. Do some forms of financial flows help protect against "sudden stops?". World Bank Economic Review 21, 389-411.

Longin, F., Solnik, B., 2001. Extreme correlation of international equity markets. Journal of Finance 56, 649-676.

Panchenko, V., Wu, E., 2009. Time-varying market integration and stock and bond return concordance in emerging markets. Journal of Banking and Finance 33, 1014-1021.

Portes, R., Rey, H., 2005. The determinants of cross-border equity flows. Journal of International Economics 65, 269-296.

Rakowski, D., Wang, X., 2009. The dynamics of short-term mutual fund flows and returns: a time-series and cross-sectional investigation. Journal of Banking and Finance 33, 2102-2109.

Razin, A., Sadka, E., Yuen, C.-W., 1998. A pecking order of capital inflows and international tax principles. Journal of International Economics 44, 45-68.

Richards, A., 2005. Big fish in small ponds: the trading behavior and price impact of foreign investors in Asian emerging equity markets. Journal of Financial and Quantitative Analysis 40,1-27.

Sapp, T., Tiwari, A., 2004. Does stock return momentum explain the "smart money" effect? Journal of Finance 59, 2605-2622.

Sarno, L., Taylor, M.P., 1999. Hot money, accounting labels and the permanence of capital flows to developing countries: an empirical investigation. Journal of Development Economics 59, 337-364.

Smith, K.A., Valderrama, D., 2009. The composition of capital inflows when emerging market firms face financing constraints. Journal of Development Economics 89, 223-234.

Warther, V.A., 1995. Aggregate mutual fund flows and security returns. Journal of Financial Economics 39, 209-235.

Yang, J., Zhou, Y., Wang, Z., 2009. The stock-bond correlation and macroeconomic conditions: one and a half centuries of evidence. Journal of Banking and Finance 33, 670-680. 